\title{
The Peripatetic Nature of EU CORPORATE TAX LAW
}

\author{
Christiana HJI PanaYi*
}

This article examines some aspects of the European Union's corporate tax set-up which correspond to aspects of a country's corporate tax regime. The overarching question is whether there is such a thing as EU corporate tax law. This article seeks to address this in the context of the following issues: the existence of a uniform tax base and tax rates; the existence of anti-abuse rules and a transfer pricing regime; and, finally, the existence of a common tax administration and its powers. The article questions whether the peripatetic development of EU corporate tax law is suitable for the EU or whether it undermines its long-term objectives. The potential impact of Brexit in the development of EU corporate tax law is also addressed.

\section{INTRODUCTION}

Although there have been rapid developments and dense harmonisation in some areas of European Union ('EU') law, in other areas progress has been rather limited. Taxation, and especially corporate taxation, is one such area. There are a number of reasons why the development of EU tax law has not kept pace with other areas of law, the most important of them being the lack of Union competence in direct tax matters and, as a corollary, the fiscal veto enjoyed by all Member States. Under the principle of attribution of powers, ${ }^{1}$ a cornerstone of the European legal structure, the Union and its institutions enjoy competence only in the areas of law assigned to or conferred on them under EU treaties. This principle of attribution of powers must be respected both internally and in the Union's external sphere of affairs. Therefore, every act must be based on a general or specific treaty provision (the legal basis) empowering the Union, expressly or impliedly, to act.

\footnotetext{
* Chair in Tax Law, Queen Mary University of London. The author would like to thank Dr Michael Blackwell for comments on an earlier draft. The contents of this article are based on materials available up to 25 July 2019.

${ }^{1}$ Treaty on European Union, opened for signature 7 February 1992 [2009] OJ C 115/13 (entered into force 1 November 1993) ('TEU') art 5.
} 
All EU treaties have been silent on direct taxation. While the treaties have dealt with indirect taxes to some extent ${ }^{2}$ they have made no reference to direct taxes. This being the case, there is no explicit legislative base for the harmonisation of direct taxes, and Member States are considered to have retained complete competence in this area. General (proxy) legislative bases under articles 115 and 352 of the Treaty on the Functioning of the European Union ('TFEU') have been used for direct tax legislation. These legislative bases focus on the attainment of the internal market ${ }^{3}$ and their use is strictly policed by the Court of Justice of the European Union ('CJEU'). The few corporate tax directives in this area were proposed (and approved by Member States in Council) on the basis of these legislative bases. ${ }^{4}$

Therefore, the EU corporate tax legislative process is actually quite simple. Corporate tax legislative proposals are invariably drafted as directives by the European Commission, most often on the basis of article 115 of the TFEU, that is, on the principle that the measures are needed for the establishment or proper functioning of the internal market. For such proposals to become EU secondary legislation, unanimity in Council is required. In other words, all Member States (in Council) have to unanimously agree to the legislative proposals. The European Parliament has no official involvement in the enactment of tax legislation. Whilst it may be consulted or it may offer its views on a matter without necessarily being asked, its role is largely advisory.

This so-called 'fiscal veto' - the power of even one Member State to veto a harmonising measure in direct tax law - has played a decisive role in the development of EU corporate tax law. The fiscal veto that Member States enjoy is a fiercely guarded prerogative which has survived successive treaty amendments and attempts to move to qualified majority voting. ${ }^{5}$ However, the

${ }^{2}$ See Treaty on the Functioning of the European Union, opened for signature 7 February 1992, [2009] OJ C 115/199 (entered into force 1 November 1993) ('TFEU') art 28 which provides for a Union based upon a customs union. See TFEU arts 30 and 110, which led to the harmonisation of excise duties. See Ben JM Terra and Peter J Wattel, European Tax Law (Kluwer Law International, $6^{\text {th }}$ ed, 2012) ch 5.

${ }^{3}$ See Claudio M Radaelli and Ulrike S Kraemer, 'Governance Areas in EU Direct Tax Policy' (2008) 46(2) Journal of Common Market Studies 315, 316.

${ }^{4}$ For a review of the corporate tax directives, see Christiana HJI Panayi, 'European Tax Law: Legislation and Soft Law' in Carsten Gerner-Beuerle et al (eds), Gore-Browne on EU Company Law (Jordan Publishing, 1991 updated) ch 18 ('European Tax Law'). Also see Christiana HJI Panayi, European Union Corporate Tax Law (Cambridge University Press, 2013) ch 2 ('EU Corporate Tax Law').

${ }^{5}$ See, for example, the draft Treaty establishing a Constitution for Europe (Constitutional Treaty) which provided for qualified majority voting for measures on company taxation when the Council unanimously found that these measures related to administrative cooperation or combated tax fraud and tax evasion. See proposed art III-63. This treaty was never ratified. See 
EU's lack of competence combined with the fiscal veto means that the regulation of direct taxes is effectively at the discretion of Member States. For this reason, the adoption of a uniform fiscal policy or a uniform corporate tax policy has proved impossible. So far, Member States have shown divergent approaches to, and appetites for, tax harmonisation in general and corporate tax harmonisation in particular. This is evident from the protracted negotiations that often take place for the adoption of, or amendments to, a directive, as with the proposals to introduce the Common Consolidated Corporate Tax Base or the Financial Transaction Tax. Both of these proposals are considered below.

It should also be noted that international direct taxation in general is not as regulated as other areas such as trade or investment. When the European Economic Community ('EEC') was created in the mid-1950s, the regulation of direct taxes was not seen as a priority; nor was it seen as an option, for that matter, due to the EEC's lack of competence. The main priority was the removal of the distortions caused by trade barriers; hence, the concentration on the harmonisation of indirect taxes. Today, the EU has a fairly harmonised system of Value Added Tax ('VAT'): a general and broadly based consumption tax assessed on the value added to goods and services. Under the EU's VAT system, the framework rules are uniform but the rates are largely left to Member States, subject to certain minimum rates. ${ }^{6}$ Even though the VAT system is considered to be harmonised, it is the Member States that collect this tax and not the EU institutions. ${ }^{7}$ Customs $^{8}$ and excises ${ }^{9}$ are also broadly harmonised in the EU and are administered in a similar way.

\footnotetext{
European Parliament, 'Draft Treaty Establishing a Constitution for Europe (not ratified)' (18 June 2004) <http://www.europarl.europa.eu/about-parliament/en/in-the-past/the-parliamentand-the-treaties/draft-treaty-establishing-a-constitution-for-europe>.

${ }^{6}$ The minimum standard VAT rate is $15 \%$ and the reduced rate is $5 \%$. There are exceptions to the rules with special rates of VAT. Also, there are rules for goods and services that are exempt from VAT and those that are subject to 0\% VAT. For a thorough analysis of the rules, see Ben Terra and Julie Kajus, A Guide to the European VAT Directives 2016 (IBFD, 2016).

${ }^{7}$ As explained below (n 17), a percentage of the VAT collected is contributed to the EU.

8 For information on the Union Customs Code, see 'Union Customs Code', European Commission (Web Page, 11 June 2019) <https://ec.europa.eu/taxation_customs/ business/union-customs-code_en>. See also Timothy Lyons, EU Customs Law (Oxford University Press, $3^{\text {rd }}$ ed, 2018).

${ }^{9}$ For information on the common EU provisions which apply to all products subject to excise duty see Council Directive 2008/118/EC of 16 December 2008 concerning the General Arrangements for Excise Duty and Repealing Directive 92/12/EEC [2008] OJ L 9/12. See also 'Common Excise Duty Provisions', European Commission (Web Page, 11 June 2019) $<$ https://ec.europa.eu/taxation_customs/business/excise-duties-alcohol-tobacco-energy/ general-overview/common-provisions_en>.
} 
The same cannot be said of direct taxation and especially corporate taxation. It is still the case today that, in principle, every country has jurisdiction to tax in any way it sees fit. Whilst there are some model tax treaties, such as the OECD Model Tax Convention ${ }^{10}$ or the UN Model Tax Convention ${ }^{11}$ which suggest ways of allocating tax jurisdiction between the source country and the taxpayer's country of residence, these models are not binding on countries, ${ }^{12}$ nor are they set in stone. In fact, these models are regularly updated in the light of new developments. Certainly, there are some pragmatic limitations affecting the tax sovereignty of countries as far as the imposition of extra-territorial taxation is concerned, these mostly being limitations on enforceability and those arising from customary international law. ${ }^{13}$ However, the regulation of their direct tax affairs, and especially the design and implementation of their corporate tax systems, is very much at the discretion of Member States.

It should be pointed out that, technically, the EU does not directly receive any yields collected under the corporate tax systems of Member States. The EU's revenue is derived from its so-called 'own resources' system, ${ }^{14}$ which includes customs duties on imports from outside the EU and sugar levies, ${ }^{15}$ a small percentage of the harmonised VAT base of each Member State, ${ }^{16}$ as well as other sources of revenue. ${ }^{17}$ The largest source of own resource is, however,

${ }^{10}$ OECD, Model Tax Convention on Income and on Capital, 21 November 2017 ('OECD Model Tax Convention').

${ }^{11}$ United Nations, United Nations Model Double Taxation Convention between Developed and Developing Countries (2017) <https://www.un.org/esa/ffd/wp-content/uploads/2018/05/MDT _2017.pdf>.

${ }^{12}$ Some countries, such as the USA, have their own models. The US Model was updated last in 2016: US Treasury, United States Model Income Tax Convention (17 February 2016) $<$ https://www.treasury.gov/resource-center/tax-policy/treaties/Documents/Treaty-US\%20 Model-2016.pdf>.

${ }^{13}$ See Christiana HJI Panayi, Double Taxation, Tax Treaties, Treaty Shopping and the European Community (Kluwer Law, 2005) chs 1-2; Lynne Oats, Angharad Miller and Emer Mulligan, Principles of International Taxation (Bloomsbury, 2017) chs 5-7; Kevin Holmes, International Tax Policy and Double Tax Treaties (IBFD, 2014) ch 2.

${ }^{14}$ See Council Decision of 26 May 2014 on the System of Own Resources of the European Union (2014/335/EU) [2014] OJ L 168/105 ('Own Resources Decision').

${ }^{15}$ EU governments keep 20\% of the amounts as collection cost. See ibid art 2(1)(a) (on traditional own resources) and art 2(3).

${ }^{16}$ This is own resources based on value added tax: ibid art 2(1)(b). The uniform rate is fixed at $0.30 \%$ (art 2(4)) but the VAT base to be taxed is capped at 50\% of the gross national income for each country. This rule is intended to prevent less prosperous countries having to pay a disproportionate amount.

${ }^{17}$ Other sources of revenue include tax and other deductions from EU staff remunerations, bank interest, contributions from non-EU countries to certain programmes, interest on late payments and fines. 
based on gross national income; each Member State transfers a percentage of its gross national income to the EU. ${ }^{18}$ Member States' contributions are not fixed and depend on what is needed to finance the balance of total expenditure not covered by the other own resources. Therefore, on a yearly basis, and depending on the financing needs of the EU, part of the corporate taxes collected by a Member State goes to the EU not because the EU has direct authority to levy corporate taxes but because they form part of the gross national income of that Member State from which a contribution must be made.

Notwithstanding this, the EU's involvement in the development of corporate tax law — at least historically ${ }^{19}$ — was not aimed at helping (or forcing) Member States to increase their corporate tax yields and, as a corollary, their contributions to the EU. Rather, the emphasis was on the impact of domestic corporate tax rules on the internal market and, more specifically, on the enjoyment of the various fundamental freedoms enshrined in the EU Treaties. The European Commission has long recognised that taxation has a significant role to play if the EU is to become the most competitive economy in the world. ${ }^{20}$ Indeed, up until 2012, the focus of attention of the European Commission was on removing tax obstacles to cross-border movement, as this would improve market access, increase competition, spur investment and innovation, and enhance the competitiveness of the EU. Since 2012, a period which broadly coincides with the launch of the OECD/G20 initiative to curb base erosion and profit splitting, ${ }^{21}$ the focus of attention seems to have shifted to dealing with aggressive tax planning and avoidance without, however, abandoning ongoing efforts to remove corporate tax obstacles in a more holistic way, as is shown below.

Broadly, what could currently be considered as the corporate tax legislation of the European Union is a patchwork of minimum rules (enacted through directives) which try to address some of the distortions caused by the coexistence of different and largely unharmonised corporate tax systems of Member States. The Merger Directive tries to deal with obstacles arising from

\footnotetext{
${ }^{18}$ See Own Resources Decision (n 14) art 2(1)(c). Correction mechanisms are designed to correct excessive contribution by certain Member States: arts 4-5.

${ }^{19}$ See Christiana HJI Panayi, 'The Early Proposals for a European Corporate Tax Policy' in Peter Harris and Dominic de Cogan (eds), Studies in the History of Tax Law (Hart Publishing, forthcoming).

${ }^{20}$ European Commission, Communication from the Commission to the Council and the European Parliament: Implementation of the Community Lisbon Programme - The Contribution of Taxation and Customs Policies to the Lisbon Strategy COM(2005) 532, 25 October 2005.

${ }^{21}$ Christiana HJI Panayi, Advanced Issues in International and European Tax Law (Hart Publishing, 2015) ch 5 ('Advanced Issues').
} 
certain types of cross-border mergers and reorganisations. ${ }^{22}$ The ParentSubsidiary Directive ${ }^{23}$ aims to alleviate double taxation arising from the crossborder payment of profit distributions (usually dividends) between group companies, under certain conditions. The Interest and Royalties Directive does the same, vis-à-vis cross-border interest and royalty payments between group companies. ${ }^{24}$ There are also minimum rules which facilitate the cooperation of Member States in recovering taxes or exchanging information. ${ }^{25}$ In addition, there are now some minimum anti-avoidance rules which endeavour to provide a common approach to some frequently used anti-avoidance techniques. ${ }^{26}$ There are also rules which help streamline tax dispute resolution involving two different competent authorities, as well as establishing mandatory arbitration. ${ }^{27}$ This body of law is buttressed by the voluminous case law of the CJEU, which sets out how the general fundamental freedoms are to be interpreted in various (often complex) corporate tax scenarios. ${ }^{28}$

This article seeks to address the overarching question: is there such a thing as EU corporate tax law? Its purpose is not to survey all of the legislative

${ }^{22}$ Council Directive 2009/133/EC of 19 October 2009 on the Common System of Taxation Applicable to Mergers, Divisions, Partial Divisions, Transfers of Assets and Exchanges of Shares Concerning Companies of Different Member States and to the Transfer of the Registered Office of an SE or SCE between Member States (codified version) [2009] OJ L 310/34 ('Merger Directive').

${ }^{23}$ Council Directive 2011/96/EU of 30 November 2011 on the Common System of Taxation Applicable in the Case of Parent Companies and Subsidiaries of Different Member States [2011] OJ L 345/8 ('Parent-Subsidiary Directive'). This has codified previous versions of the Directive: Council Directive 90/435/EEC of 23 July 1990 on the Common System of Taxation Applicable in the Case of Parent Companies and Subsidiaries in Different Member States, amended by Council Directive 2003/123/EC of 22 December 2003 [2011] OJ L 345/8.

${ }^{24}$ Council Directive 2003/49/EC of 3 June 2003 on a Common System of Taxation Applicable to Interest and Royalty Payments Made between Associated Companies of Different Member States OJ L 157/49, amended by Council Directive 2004/66/EC of 26 April 2004, Council Directive 2004/76/EC of 29 April 2004 and Council Directive 2006/98/EC of 20 November 2006 ('Interest and Royalties Directive').

${ }^{25}$ See Council Directive 2010/24/EU of 16 March 2010 concerning Mutual Assistance for the Recovery of Claims Relating to Taxes, Duties and Other Measures) [2010] OJ L 84/1 ('Mutual Assistance for the Recovery of Claims Directive') and Council Directive 2011/16/EU of 15 February 2011 on Administrative Cooperation in the Field of Taxation [2011] OJ L 64/1 ('DAC').

${ }^{26}$ See Council Directive (EU) 2016/1164 of 12 July 2016 Laying Down Rules against Tax Avoidance Practices that Directly Affect the Functioning of the Internal Market [2016] OJ L 193/1.

${ }^{27}$ Council Directive (EU) 2017/1852 of 10 October 2017 on Tax Dispute Resolution Mechanisms in the European Union [2017] OJ L 265/1 ('Tax Dispute Resolution Directive').

${ }^{28}$ Christiana HJI Panayi, 'European Community Tax Law and Companies: Principles of the European Court of Justice' in Carsten Gerner-Beuerle et al (eds), Gore-Browne on EU Company Law (Jordan Publishing, 1991 updated) ch 19 ('European Community Tax Law'). 
instruments or case law relevant to the EU's corporate tax law. Rather, the aim of this article is to determine whether a common corporate tax regime exists by reviewing some aspects of the EU's corporate tax set-up which correspond to aspects of a country's corporate tax regime in the context of the following issues: the existence of a uniform tax base and tax rates; the existence of antiabuse rules and a transfer pricing regime; and, finally, the existence of a common tax administration and its powers. The article questions whether the peripatetic development of EU corporate tax law is suitable for the EU or whether it undermines its long-term objectives. The potential impact of Brexit in the development of EU corporate tax law is also addressed in the final Part of this article.

\section{An EU Corporate Tax Base and TaX Rate?}

Broadly, a corporate tax base is the set of rules upon which the assessment or determination of corporate tax liability is based. In the European Union, there is no harmonised corporate tax base nor a common tax rate - at least not yet. However, there have been on-going efforts to create a common corporate tax base to facilitate cross-border corporate groups.

In its ground-breaking 2001 study, Company Taxation in the Internal Market, ${ }^{29}$ the European Commission recommended a single set of rules to calculate the taxable profits of companies in the EU. This study set the parameters for a very important proposal in the area of corporate tax law — the proposal for a common tax base and consolidation. As an alternative to targeted solutions, the possibility of adopting a comprehensive solution was examined. It was reiterated numerous times in the 2001 study $^{30}$ that the existence of 15 tax systems (at the time) was the source of most of the tax obstacles to cross-border movement. Several comprehensive measures predicated on a single tax base were broadly considered by the European Commission, though it was noted that these approaches were not developed in detail. It was noted that 'given that all Member States are committed to exploiting the opportunities of the Internal Market to the maximum, there is certainly a case for continuing and extending the research into these possibilities'. ${ }^{31}$

Ever since the publication of the 2001 Company Tax Study, the European Commission had been working on a project for a Common Consolidated Corporate Tax Base (CCCTB). On 16 March 2011, the European Commission

\footnotetext{
${ }^{29}$ European Commission, Company Taxation in the Internal Market SEC(2001) 1681, 373.

${ }^{30}$ Ibid 2, 8, 14, 372.

${ }^{31}$ Ibid 419.
} 
published the eagerly awaited first official proposal for the CCCTB.${ }^{32}$ Broadly, the 2011 CCCTB proposal provided companies with establishments in at least two Member States with detailed optional rules to compute their group taxable income according to one set of rules, those of the new consolidated tax base, rather than according to the national tax bases of each Member State. The overall aim of the CCCTB was to reduce the costs of complying with 27 (at the time) tax regimes, to minimise tax arbitrage and to simplify restructurings. It was also aimed at providing comprehensive consolidation of profits and losses on an EU basis. ${ }^{33}$ In other words, the CCCTB was essentially proposed as a $28^{\text {th }}$ system - all Member States would adopt it as an alternative to their existing corporate tax systems. The European Commission extolled the proposal for offering companies a 'one-stop-shop' system for filing their tax returns, as well as provide for consolidation. This would translate into savings in compliance time and costs. ${ }^{34}$ It was also claimed that the new system would bring tangible benefits for companies wishing to expand into other Member States. ${ }^{35}$

Although the proposal was not immediately curbed on the basis of subsidiarity and enjoyed the support of the European Parliament, which in fact advocated for its mandatory application ${ }^{36}$ not much happened thereafter. After years of technical discussions in Council, it was clear that some of the provisions of the original CCCTB proposal, and especially consolidation, were too ambitious to be adopted all at once. Several Member States and, in particular, the UK were opposed to this proposal, as they would lose much of their power to determine corporate tax policy. Smaller Member States were also concerned that formulary apportionment under this proposal would have the overall effect of

32 European Commission, Proposal for a Council Directive on a Common Consolidated Corporate Tax Base (CCCTB) COM(2011), 121 final, 16 March 2011.

${ }^{33}$ See European Commission, 'European Corporate Tax Base: Making Business Easier and Cheaper' (Press Release, IP/11/319, 16 March 2011) <http://europa.eu/rapid/press-release_IP11-319_en.htm>.

${ }^{34}$ The Commission estimated that the CCCTB would save businesses across the EU $€ 700$ million in reduced compliance costs, $€ 1$ billion in reduced costs to expand cross-border and $€ 1.3$ billion through consolidation. It was also estimated that businesses looking to expand cross-border would benefit from up to $€ 1$ billion in savings. See ibid. See also 'Questions and Answers on the CCCTB', European Commission (Memo, MEMO/11/171, 16 March 2011) 2 ('Memo/11/171').

${ }^{35} \mathrm{Memo} / 11 / 171$ (n 34) 5.

${ }^{36}$ See European Parliament legislative resolution of 19 April 2012 on the proposal for a Council directive on a Common Consolidated Corporate Tax Base (CCCTB) (COM(2011)0121 - C70092/2011-2011/0058(CNS)). 
shifting tax revenues to larger countries with larger markets such as France and Germany. ${ }^{37}$

It was widely thought that discussions on the more controversial aspects of the proposal - notably, consolidation and formulary apportionment - were holding back progress on other less controversial but still important areas, which could be agreed more quickly. Furthermore, the 2011 CCCTB proposal was very much overshadowed by the high profile OECD/G20 Base Erosion and Profit Shifting ('BEPS') initiative ${ }^{38}$ and the EU's eager response to this initiative. ${ }^{39}$ Arguably, the 2011 CCCTB proposal had to be adjusted to be perceived as truly effective in tackling aggressive tax planning and not merely as a tool to reduce compliance costs for multinationals.

With the appointment of Jean-Claude Juncker as President of the European Commission, interest in the CССТВ was reinvigorated. In October 2015, a consultation on the relaunch of the CCCTB was published ${ }^{40}$ and in the 2015 Action Plan for a Fair and Efficient Corporate Tax System ${ }^{41}$ the European Commission announced that it would relaunch the CCCTB the following year. This was to be done through a two-step approach: Member States would first

${ }^{37}$ See Robert Cline et al, Study on the Economic and Budgetary Impact of the Introduction of a Common Consolidated Corporate Tax Base in the European Union (Ernst \& Young, 2011). The Study was commissioned by the Irish Department of Finance from Ernst \& Young in 2010. See also Michael Devereux and Simon Loretz, The Effects of EU Formula Apportionment on Corporate Tax Revenues (Working Paper No 0706, Oxford University Centre for Business Taxation, 2007).

${ }^{38}$ BEPS refers to tax avoidance strategies that exploit gaps and mismatches in tax rules to artificially shift profits to low or no-tax locations. With the backing of G20 member countries, in 2013, the OECD published 15 Action items to address the main areas where it was felt that companies had been most aggressively accomplishing base erosion and profit shifting. See OECD, Action Plan on Base Erosion and Profit Shifting (2013) ('BEPS Action Plan') $<$ http://www.oecd.org/ctp/BEPSActionPlan.pdf >. The Final Reports on these action items contained several non-binding recommendations: OECD, 'BEPS 2015 Final Reports' (Web Page, 5 October 2015) <http://www.oecd.org/tax/beps-2015-final-reports.htm>. The OECD and G20 member countries made a political commitment to adopt the four minimum standards. The BEPS minimum standards are the following: (1) the prevention of harmful tax practices and through the automatic exchange of information on tax rulings (Action 5); (2) countering treaty shopping (Action 6); (3) country-by-country reporting (Action 13); and (4) improving dispute resolution (Action 14).

${ }^{39}$ HJI Panayi, Advanced Issues (n 21) chs 5-6.

${ }^{40}$ See 'Consultation on the Re-launch of the Common Consolidated Corporate Tax Base (CCCTB)' European Commission (Web Page) <http://ec.europa.eu/taxation_customs/ common/consultations/tax/relaunch_ccctb_en.htm>.

${ }^{41}$ European Commission, Communication from the Commission to the European Parliament and the Council, 'A Fair and Efficient Corporate Tax System in the European Union: 5 Key Areas for Action' COM(2015)302 final, 17 June 2015 ('A Fair and Efficient Corporate Tax System'). 
agree on rules for a common tax base, after which agreement would be reached on the consolidation element. Neither the original proposal published in $2011,{ }^{42}$ nor the later 2016 proposals, involved changes to Member States' corporate tax rates. Indeed, the proposals relaunched in October 2016 consisted of two separate directives, one for a common corporate tax base (the CCTB $)^{43}$ and the other, again, for a common consolidated corporate tax base (the CCCTB). ${ }^{44}$ The difference between the CCTB and the CCCTB is that the latter provides for cross-border consolidation of profits and losses, as well as for the elimination of intra-group transactions. Certainly, the momentum generated by the BEPS project helped fast-track this relaunch, as under the new proposals the focus of attention shifted from the objective of facilitating corporate groupings and simplifying compliance to countering tax avoidance.

The first important feature of the original and the subsequent proposals is the provision for a common tax base. There are uniform rules for the calculation of the tax base of group members that fall under the scope of the draft Directives. The second important feature of the proposals is consolidation, that is, the automatic set-off of profits and losses and the elimination of intra-group transactions for group members. One important difference between the 2011 and the 2016 proposals is that the provisions for consolidation have now been moved to a different directive so that there can at least be progress with the common tax base. Another important difference between the 2016 CCTB/CCCTB proposals and the 2011 CCCTB proposal is that the new rules (that is, the common tax base and subsequent consolidation) are mandatory for large corporate groups - defined as groups with a consolidated turnover exceeding $€ 750 \mathrm{~m} .{ }^{45}$ It is no longer an option for eligible groups to opt in to the new tax base, as it was in the 2011 proposal. However, companies falling outside the scope of the proposed directive ${ }^{46}$ may opt to apply its rules under certain conditions (voluntary opt-in). ${ }^{47}$ Therefore, the CCTB/CCCTB

42 European Commission, Proposal for a Council Directive on a Common Consolidated Corporate Tax Base (CCCTB) $\operatorname{COM(2011),~} 121$ final, 16 March 2011. See generally HJI Panayi, EU Corporate Tax Law (n 4) ch 3. See also Christiana HJI Panayi, The Common Consolidated Corporate Tax Base and the UK (Institute for Fiscal Studies, 2011) ('Common Consolidated Corporate Tax Base').

${ }^{43}$ European Commission, Proposal for a Council Directive on a Common Corporate Tax Base, $\operatorname{COM}(2016) 685$ final, 25 October 2016 <https://ec.europa.eu/taxation_customs/sites/ taxation/files/com_2016_685_en.pdf> ('Draft CCTB Directive').

${ }^{44}$ European Commission, Proposal for a Council Directive on a Common Consolidated Corporate Tax Base, $\operatorname{COM}(2016) 683$ final (25 October 2016) <http://ec.europa.eu/ taxation_customs/sites/taxation/files/com_2016_683_en.pdf> ('Draft CCCTB Directive').

${ }^{45}$ See Draft CCTB Directive (n 433) art 2(1)(c).

${ }^{46}$ Ibid art 2.

${ }^{47}$ Ibid art 2(3). 
proposals, if enacted, would replace Member States' corporate tax bases for eligible taxpayers rather than provide an additional optional tax base to choose from.

Furthermore, the proposed rules are limited to EU-resident companies (the qualifying subsidiaries ${ }^{48}$ and EU permanent establishments. Contrary to the 2011 CCCTB proposal, the revised permanent establishment definition refers only to permanent establishments situated in the $\mathrm{EU}$ and belonging to a taxpayer resident for tax purposes in the EU. EU permanent establishments of third country companies are not covered; their position is to be dealt with in bilateral tax treaties and national law.

The new common tax base is designed broadly. It is stipulated in the Preamble that all revenues will be taxable unless expressly exempted. ${ }^{49}$ The basic formulation of the tax base is the following: revenues less exempt revenues, deductible expenses and other deductible items. ${ }^{50}$ All these concepts are defined in the proposals. There is also a list of non-deductible expenses. ${ }^{51}$ The 2016 CCTB proposal (like the original 2011 proposal) also contains detailed rules on depreciation. ${ }^{52}$ For the purposes of calculating the tax base, transactions are measured by reference, inter alia, to monetary consideration and market value. ${ }^{53}$

What is novel in the 2016 CCTB proposal is the very generous provision for deduction: the super-deduction for research and development ('R\&D') costs. It is provided that, on top of the amounts already deductible for R\&D costs, a deduction of an extra 50\% of R\&D costs each tax year will be granted for costs up to $€ 20 \mathrm{~m}$ and $25 \%$ for expenditure above this level. An enhanced $100 \%$ extra deduction will be available to start-ups for R\&D expenditure up to $€ 20 \mathrm{~m} .{ }^{54}$ The CCTB does not provide for a patent or innovation box type of rules (that is, low or no taxes for patent revenue), but this is thought to be a good alternative to entice Member States to agree to the proposal and abandon their own patent box regimes. It will also help attract high-value R\&D activities to the EU.

\footnotetext{
${ }^{48} \mathrm{~A}$ 'qualifying subsidiary' is defined as every immediate and lower-tier subsidiary in which the parent company has a right to exercise more than $50 \%$ of the voting rights and it has an ownership right amounting to more than $75 \%$ of the subsidiary's capital or profit: ibid art 5(1).

${ }^{49}$ Ibid Preamble 9.

${ }^{50}$ Ibid art 7.

${ }^{51}$ Ibid art 12.

${ }^{52}$ Ibid ch IV, arts 30-40.

${ }^{53}$ Ibid art 20.

${ }^{54}$ Ibid art 9(3).
} 
Another addition to the CCTB proposal is the allowance for growth and investment ('AGI'), which was inserted to neutralise the current asymmetry between debt and equity financing. ${ }^{55}$ The AGI is defined as the difference between the equity of a taxpayer and the tax value of its participation in the capital of associated enterprises ${ }^{56}$ Pursuant to this rule, taxpayers will be given a deduction in respect of a notional yield on defined increases in their equity (the AGI equity base). ${ }^{57}$ This will be deductible from their taxable base subject to certain conditions dealing with anti-tax avoidance. In case of an AGI equity base decrease, an amount equal to the notional yield of the AGI equity decrease shall become taxable. 'The outcome is a definitive advantage in favour of financing through debt as opposed to equity.' 58

The original 2011 CCCTB proposal and the 2016 CCCTB proposal set out the conditions for the formation of a consolidated tax group, as well as the mechanism for formulary apportionment and allocation of the consolidated tax base to the relevant Member States. In addition, there are rules for entering and leaving a group, the treatment of losses, business reorganisations and the intragroup transfer of assets. Consolidation is mandatory to all groups that fall within the scope of the CCTB proposal, that is, groups with a consolidated group revenue exceeding $€ 750 \mathrm{~m}$. The formula for apportionment is identical to the one proposed in the 2011 CCCTB proposal and is based on three equallyweighted factors: labour, assets and sales. ${ }^{59}$ As in the 2011 proposal, intangible assets are excluded from the base of the asset factor and the sales factor is sales by destination. ${ }^{60}$ The 2016 CCCTB proposal also contains sector-specific formulae for financial institutions, ${ }^{61}$ insurance, ${ }^{62}$ oil and gas,${ }^{63}$ shipping and air transport. ${ }^{64}$

As in the original proposal, there are detailed administrative provisions for consolidated groups. ${ }^{65}$ The CCCTB is meant to offer qualifying groups a onestop-shop approach; the group would deal with one Member State tax

\footnotetext{
55 Ibid art 11.

${ }^{56}$ Ibid art 11(1).

${ }^{57}$ Ibid art 11(3).

${ }^{58}$ See Explanatory Memorandum preceding the draft CCTB Directive (n 43) 10.

${ }^{59}$ See Draft CCCTB Directive (n 44) ch VIII.

${ }^{60}$ Ibid arts 37-38.

${ }^{61}$ Ibid art 40 .

${ }^{62}$ Ibid art 41.

${ }^{63}$ Ibid art 42.

${ }^{64}$ Ibid art 43 .

${ }^{65}$ Ibid ch IX.
} 
administration in the EU, which is usually the Member State where the group's parent company is resident for tax purposes. ${ }^{66}$

It should be emphasised that neither the initial CCCTB proposal, nor the subsequent ones, affect tax rates. The draft directives seek to harmonise the tax base and not the tax rates, though there have been unofficial calls to impose a minimum corporate tax rate. ${ }^{67}$ The CCTB/CCCTB determines the portion of the consolidated tax base that belongs to a Member State. Member States will be entitled to tax the income apportioned to them according to their own rates. This was emphasised by the European Commission upon the release of the original CCCTB Directive ${ }^{68}$ and reiterated in the press release of the subsequently proposed CCTB/CCCTB Directives. As stated:

Corporate tax rates are not covered by the CCCTB, as these remain an area of national sovereignty. However, the CCCTB will create a more transparent, efficient and fair system for calculating the tax base of cross-border companies, which will substantially reform corporate taxation throughout the EU. ${ }^{69}$

Although the CCCTB is not meant to affect tax rates (just the taxable income that will be apportioned to the relevant countries), if approved, it will reform the rules on corporate taxation in the EU - mainly in regard to multinationals. ${ }^{70}$

\footnotetext{
${ }^{66}$ See ibid for detailed rules.

${ }^{67} \mathrm{See}$, eg, the call for a $25 \%$ rate by the European Trade Union Confederation: 'ETUC Position on the Common Consolidated Corporate Tax Base (CCCTB)', European Trade Union Confederation (Web Page, 16 October 2016) <https://www.etuc.org/en/document/etucposition-common-consolidated-corporate-tax-base-ccctb>. There has also been speculation that France and Germany want a minimum corporate tax rate. See Matthew Holehouse and Christopher Williams, 'France and Germany Behind Plans for "Common EU Corporation Tax"', The Telegraph (online, 26 May 2015) <https://www.telegraph.co.uk/news/worldnews/ europe/eu/11630468/France-and-Germany-behind-plans-for-common-EU-corporationtax.html> and Ruth Berschens, Donata Riedel and Christopher Cermak, 'EU: Shut Tax Havens with Minimum Rate', Handelsblatt (online, 26 May 2015) <https://global.handelsblatt.com/ finance/a-tax-collision-course-223953>. In late 2018, it was reported that Germany wanted a minimum tax for large technology companies. See Mallory Locklear, 'Germany Calls for Global Minimum Tax on Large Tech Companies', Engadget (Web Page, 22 October 2018) $<$ https://www.engadget.com/2018/10/22/germany-global-minimum-tax-large-techcompanies/>.

${ }^{68}$ HJI Panayi, Common Consolidated Corporate Tax Base (n 42).

${ }^{69}$ See 'Commission Proposes Major Corporate Tax Reform for the EU', European Commission (Press Release, 25 October 2016) <http://europa.eu/rapid/press-release_IP-16-3471_en.htm>.

${ }^{70}$ See Centre for European Economic Research, 'The Impact of the CCTB on the Effective Tax Burden of Corporations: Results from the Tax Analyzer Model' (Working Paper 75-2019, European Commission, 2019) <https://ec.europa.eu/taxation_customs/sites/taxation
} 
Whether there will be a spill-over effect on domestic corporate tax rules affecting taxpayers with a consolidated group revenue of less than $€ 750$ million remains to be seen. Furthermore, whether the harmonisation of the rules on the corporate tax base will also eventually lead to the harmonisation of tax rates (or the creation of bands of rates) also remains to be seen. Even though the 2016 CCTB/CCCTB proposals have not yet been adopted, they remain high on the agenda of the European Commission, with several compromise texts appearing since the first relaunch. ${ }^{71}$

Interestingly, there are currently two pending proposals that provide for the imposition of a tax and at a certain rate. One is a long-standing proposal for the imposition of a financial transaction tax and the other is a recent proposal for a $3 \%$ digital services tax.

The Directive to introduce a common system of Financial Transaction Tax (FTT) was published in 2011. ${ }^{72}$ The FTT was largely a reactive measure to the financial crisis, engulfing the EU (and the rest of the world) at the time. The FTT was indeed hailed as a levy imposed to ensure that the financial sector contributed to the costs of the financial crisis. The FTT was also meant to discourage excessively risky activities by financial institutions but it was not meant to affect citizens and businesses. It would only apply if one of the two parties was a financial institution and if one of the two parties - whether the financial institution or the non-financial institution - was established in a Member State. ${ }^{73}$ A tax of $0.1 \%$ for most financial transactions other than derivatives and $0.01 \%$ for derivative contracts was proposed. These were minimum rates and participating Member States were entitled to apply higher rates. It was proposed that each financial institution that was a party to the financial transaction would pay the tax and there would be joint and several liability as regards this charge. The European Commission estimated revenues

\footnotetext{
/files/taxation_paper_75.pdf>. This recent working paper explores the potential impact of the introduction of a Common Corporate Tax Base on the tax burden of corporations.

${ }^{71}$ See the latest Romanian Presidency compromise text of the Proposal for a Council Directive on a Common Corporate Tax Base (CCTB) published by the Council of the European Union in June 2019: Proposal for a Council Directive on a Common Corporate Tax Base (CCTB), $\operatorname{COM}(2016) 685$ final (6 June 2019) <https://data.consilium.europa.eu/doc/document/ST9676-2019-INIT/en/pdf>. See also the previous Austrian Presidency compromise text published in December 2018: Proposal for a Council Directive on a Common Corporate Tax Base (CCTB), COM(2016) 685 final (5 December 2018) <https://data.consilium. europa.eu/doc/document/ST-13024-2018-INIT/en/pdf>.

${ }^{72}$ European Commission, Proposal for a Council Directive on a Common System of Financial Transaction Tax and amending Directive 2008/7/EC, COM(201) 594 final, 28 September 2011 ('2011 FTT Proposal').

${ }^{73}$ For an analysis of the proposed rules, see HJI Panayi, Advanced Issues (n 21) ch 8.
} 
of approximately $€ 57$ billion annually without clearly stipulating how the revenue would be used. It was thought that some of it would be allocated to the EU Budget, thus reducing the contributions of Member States.

The proposed directive was never approved. From the beginning, the proposal was not seen favourably by a number of Member States, especially the UK, Sweden, Bulgaria, the Czech Republic, Cyprus, Malta and Denmark. By June 2012 at the Economic and Financial Affairs Council ('ECOFIN') meeting, it became clear that the European Commission's proposal would not gather the necessary support to be unanimously adopted by Member States. It could only be adopted through the enhanced cooperation procedure set out under the EU Treaties, ${ }^{74}$ which requires a minimum of nine Member States to adopt a legislative measure between themselves even if not all Member States agree to this measure.

Adoption of this proposal through enhanced cooperation was instigated by Germany and France and eventually supported by the European Commission on 23 October 2012. The FTT proposal, backed by 10 Member States at the time and eventually by 11 Member States (Austria, Belgium, Finland, France, Germany, Greece, Italy, Portugal, Spain, Slovenia and Slovakia) was approved by the European Parliament in December 2012. In January 2013, the adoption of the FTT through enhanced cooperation was approved by qualified majority at the ECOFIN Council. The UK, Luxembourg, Malta and the Czech Republic raised concerns that the European Commission had not provided any analysis of the impacts that an FTT through enhanced cooperation would have on individual Member States. The dissenting Member States abstained from voting.

Thereafter, on 14 February 2013, the European Commission published a proposal for a Council directive implementing enhanced cooperation in the area of financial transaction tax ${ }^{75}$ accompanied by another Impact Assessment. ${ }^{76}$ There were some differences in the new proposal ${ }^{77}$ and the revenue estimate

\footnotetext{
${ }^{74}$ TEU (n 1) art 20 and TFEU (n 2) arts 326-334.

75 European Commission, Proposal for a Council Directive Implementing Enhanced Cooperation in the Area of Financial Transaction Tax, COM(2013)71 final, 14 February 2013.

76 European Commission, Commission Staff Working Document, 'Impact Assessment Accompanying the Document Proposal for a Council Directive Implementing Enhanced Cooperation in the Area of Financial Transaction Tax: Analysis of Policy Options and Impacts' SWD(2013) 28 final, 14 February 2013.

${ }^{77}$ Compared to the 2011 FTT Proposal (n 73), the most important change was the introduction of the issuance principle, whereby financial instruments issued in the participating Member States will be taxed when traded, even if the parties trading them were not established in FTT Member States. This principle was thought to be the most contentious recommendation and in
} 
was adjusted to $€ 30-35$ billion per year. Part of this would be added to the EU Budget directly as an own resource, reducing the contributions of participating Member States accordingly. This proposal had to be unanimously approved by the participating Member States to be adopted by them.

The European Commission's revised proposal was met with strong disapproval by the UK. Eventually, the UK Government challenged the authorising decision to adopt the FTT through enhanced cooperation at the CJEU, ${ }^{78}$ arguing that it would have extraterritorial effect and would result in non-participating Member States incurring implementation and collection costs. The CJEU rejected the UK's request on the basis that its arguments were founded on the draft Directive, which was not part of the decision to authorise the use of enhanced cooperation. ${ }^{79}$ The gist of the decision was that, if and when an FTT is adopted under enhanced cooperation, it may be possible to challenge the measures at that point. Therefore, a subsequent challenge could be admissible, depending on the form and scope of any FTT.

Even though this decision effectively gave participating countries the green light to proceed with enhanced cooperation, the FTT proposal is yet to be adopted. With Brexit, there are lingering doubts as to whether the FTT will go forward if its provisions do not apply to the UK, notwithstanding intermittent attempts by some Member States to force through the adoption of this proposal (or versions of it). ${ }^{80}$

Another proposal which stipulates the imposition of a tax is the recent proposal for a digital services tax. This proposal was one of a high-profile package of

\footnotetext{
certain circumstances it could have extraterritorial effects. A General Anti-Abuse Rule has also been inserted. See HJI Panayi, Advanced Issues (n 21) ch 8 and Christiana HJI Panayi, 'The EU's Financial Transaction Tax, Enhanced Cooperation and the UK's Challenge' (2013) 53(8) European Taxation 358.

${ }^{78}$ United Kingdom v Council (CJEU, C-209/13, 30 April 2014).

${ }^{79}$ The review of the Court of Justice was limited to the issue of whether that decision was valid in light of art 20 TEU (n 1) and arts 326-334 TFEU (n 2), which defined the substantive and procedural conditions relating to the granting of such authorisation. The Court of Justice found the challenge to be premature.

${ }^{80}$ Since 2018, there have been reports that French and German finance ministers have suggested the relaunch of the FTT, and its adoption by all Member States. See Andrea Shalal, 'Germany and France to Outline EU Financial Transaction Tax Proposal - Newspaper', Reuters (Web Page, 2 December 2018) <https://uk.reuters.com/article/uk-europe-tax-germany-france/ germany-and-france-to-outline-eu-financial-transaction-tax-proposal-newspaper-idUKKBN 1O10RN>. In January 2019 Germany and France fleshed out their plans and presented a joint position paper, which was referred to in the most recent ECOFIN progress report on the FTT. See Council of the European Union, State of Play of the Financial Transaction Tax (7 June 2019) <https://data.consilium.europa.eu/doc/document/ST-10097-2019-INIT/en/pdf>.
} 
proposals, intended to introduce a 'Fair and Effective Tax System in the EU for the Digital Single Market'. ${ }^{81}$ Although the international tax community had also attempted to tackle some of the problems arising in taxing the digital economy in the context of the BEPS project, it did not produce any concrete recommendations (or minimum standards). ${ }^{82}$ The EU has been much bolder in this area. In an earlier report published in 2014 by the EU Expert Group on Taxation of the Digital Economy, ${ }^{83}$ it was recommended that all goods and services should be taxed at the place of consumption. ${ }^{84}$ Whilst the Group argued that there was no need for a new concept of digital taxable presence; nevertheless, later initiatives focused on this point. Following a communication on a fair and efficient tax system for the single digital market in the European Union, ${ }^{85}$ on 21 March 2018, the European Commission produced several proposals, setting out its vision of short-term and long-term legislative measures. ${ }^{86}$ One of these was a proposal for a directive on the introduction of a digital permanent establishment concept based on significant digital presence. Another proposal was for a directive on a digital services tax. These proposals were accompanied by a Recommendation to Member States to amend their tax treaties with third countries so that the same rules would apply to EU and nonEU companies.

${ }^{81}$ See European Commission, Communication from the Commission to the European Parliament and the Council, A Fair and Efficient Tax System in the European Union for the Digital Single Market, COM(2017) 547 final, 21 September 2017.

${ }^{82}$ See OECD, Addressing the Tax Challenges of the Digital Economy, Action 1-2015 Final Report, OECD/G20 Base Erosion and Profit Shifting Project (OECD Publishing, 2015) Paris, $12<$ https://read.oecd-ilibrary.org/taxation/addressing-the-tax-challenges-of-the-digitaleconomy-action-1-2015-final-report_9789264241046-en\#page1>. See also the more recent OECD interim report in this area: OECD, Tax Challenges Arising from Digitalisation - Interim Report 2018: Inclusive Framework on BEPS, OECD/G20 Base Erosion and Profit Shifting Project (OECD Publishing, 2018) <https://doi.org/10.1787/9789264293083-en>.

${ }^{83}$ European Commission, Report of the Commission Expert Group on Taxation of the Digital Economy (28 May 2014) 5 <https://ec.europa.eu/taxation_customs/sites/taxation/files/ resources/documents/taxation/gen_info/good_governance_matters/digital/report_digital_econ omy.pdf>.

${ }^{84}$ The Expert Group on Taxation of the Digital Economy suggested that the EU Mini One Stop which at the time already covered business-to-consumer sales of telecommunications, television/radio broadcasting and electronic services should be expanded into a broad One Stop Shop to cover all business-to-consumer transactions. See HJI Panayi, Advanced Issues (n 21) ch 5 .

${ }^{85}$ European Commission, Communication from the Commission to the European Parliament and the Council, A Fair and Efficient Tax System in the European Union for the Digital Single Market, $\operatorname{COM(2017)~} 547$ final, 21 September 2017.

${ }^{86}$ Also see European Commission, Communication from the Commission to the European Parliament and the Council, Time to Establish a Modern, Fair and Efficient Taxation Standard for the Digital Economy, COM(2018)146 final, 21 March 2018. 
The first legislative proposal for a digital permanent establishment represents a long-term measure for taxing the digital economy. The proposal enables taxation of profits from digital activities, insofar as such profits are attributable to a significant digital presence maintained by entities (EU or non-EU) in a Member State. ${ }^{87}$ There are rules as to when significant digital presence is deemed to exist, and how to determine the profits which are attributable to it. Through its Recommendation, ${ }^{88}$ the European Commission also put forward a proposal to amend existing tax treaties between Member States and third countries to incorporate the new rules. Overall, this is a proposal which will affect the tax base of a Member State, as it establishes when certain activities would be taxable for giving rise to a permanent establishment in the State.

The second legislative proposal which is important for our purposes represents a short-term measure: the introduction of a digital services tax on revenues resulting from the provision of certain digital services. ${ }^{89}$ The digital services tax will apply at the rate of $3 \%$ on gross revenues created from activities where users have played a major role in value creation, for example through selling online advertising space; making available to users a multi-sided digital interface; and transmission of data collected about users and generated from users' activities on digital interfaces. This approach follows the logic that it was the user's involvement in the digital activities of a company which generated the value for that company, even though the user may have made no payment to the company. ${ }^{90}$ Only entities with total annual worldwide revenues of $€ 750$ million and EU taxable revenues of $€ 50$ million will be subject to this tax, irrespective of whether they are established in a Member State or third country. The European Commission estimated that $€ 5$ billion per year could be generated for Member States if the tax were applied at a rate of $3 \% .^{91}$

Luxembourg and Ireland have vehemently opposed the digital services tax, calling for discussions on a global approach at the OECD level. Opposition to the European Commission's proposals is also growing, with Lithuania, the Czech Republic, Malta and several Nordic countries thought to be against the

${ }^{87}$ European Commission, Proposal for a Council Directive Laying Down Rules Relating to the Corporate Taxation of a Significant Digital Presence, COM(2018) 147 final, 21 March 2018.

${ }^{88}$ European Commission, Commission Recommendation of 21.3.2018 Relating to the Corporate Taxation of a Significant Digital Presence, C(2018) 1650 final, 21 March 2018.

${ }^{89}$ European Commission, Proposal for a Council Directive on the Common System of a Digital Services Tax on Revenues Resulting from the Provision of Certain Digital Services, $\operatorname{COM}(2018) 148$ final, 21 March 2018.

${ }^{90}$ Ibid 11.

${ }^{91}$ See 'Questions and Answers on a Fair and Efficient Tax System in the EU for the Digital Single Market', European Commission (Fact Sheet, 21 March 2018) <http://europa. eu/rapid/press-release_MEMO-18-2141_en.htm>. 
proposals. ${ }^{92}$ Even Member States that were initially in favour of an EU solution are now more reluctant to adopt such a solution - or at least this EU solution. ${ }^{93}$ One recurrent argument is that this shift in taxing rights based on the location of the digital user is a major deviation from internationally recognised taxation principles and should be agreed upon first at an international level and not by the EU unilaterally. Even the European Parliament has proposed ${ }^{94}$ that a sunset clause should be introduced, under which a digital services tax would be a temporary levy valid until an agreement has been reached internationally. It was also recommended that the Member States most adversely affected by the introduction of the tax could be allocated a greater part of the revenue from the interim tax. ${ }^{95}$

Against this background, unsurprisingly, at the December 2018 ECOFIN meeting, the Austrian Presidency did not gain the necessary support for the proposal to be approved. This notwithstanding the fact that France and Germany had presented a joint compromise proposal to narrow the scope of the digital services tax proposal, with a view to targeting exclusively companies engaged in online advertising. Similarly, at the March 2019 ECOFIN meeting, Member States again did not reach agreement on the proposed digital advertising tax, which was effectively a watered-down version of the European Commission's digital services tax proposal. This was due to opposition by Nordic countries and Ireland. The Romanian Presidency noted that Member States and the Council would continue to work in this area in order to reach consensus before the G20's summit in Osaka, in June 2019. No consensus was, however, reached by that point in time, due to the strong divergent views of Member States. ${ }^{96}$ Whether this or another watered-down version of the European Commission's digital tax proposals will be eventually approved, or

\footnotetext{
${ }^{92}$ See HJI Panayi, ‘European Tax Law' (n 4) [22].

${ }^{93}$ For example, even Germany had its misgivings about the initial proposal after automakers expressed concern they would be hit by the tax. See Timothy Rooks, 'Taxes Coming to Big Data in Germany?', DW (Web Page, 29 May 2018) <https://www.dw.com/en/taxes-comingto-big-data-in-germany/a-43972540>.

${ }^{94}$ See European Parliament, Draft Report on the Proposal for a Council Directive on the Common System of a Digital Services Tax on Revenues Resulting from the Provision of Certain Digital Services (COM(2018)0148 - C8-0137/2018 - 2018/0073(CNS)), 21 September 2018. <http://www.europarl.europa.eu/sides/getDoc.do?pubRef=-\%2f\%2fEP\%2f\%2fNONSGML\% 2bCOMPARL $\% 2 \mathrm{bPE}-627.911 \% 2 \mathrm{~b} 01 \% 2 \mathrm{bDOC} \% 2 \mathrm{bPDF} \% 2 \mathrm{bV0} \% 2 \mathrm{f} \% 2 \mathrm{fEN}>$.

${ }^{95} \mathrm{Ibid}$. Other amendments included a rate increase from $3 \%$ to $5 \%$ and a broadening of the scope to cover the supply of digital content and online sales.

${ }^{96}$ See conclusions of the ECOFIN meeting on 17 May 2019: 'Outcome of the Council Meeting, $3691^{\text {st }}$ Council Meeting' ECOFIN, 9434/19 (17 May 2019) 4 <https://www.consilium. europa.eu/media/39434/st09434-en19.pdf>.
} 
whether these controversial proposals will follow the fate of the beleaguered proposal for a Financial Transaction Tax, remains to be seen.

In any case, any Commission proposals that include uniform rules on calculating the tax base and imposing tax rates are likely to meet with strong resistance from Member States. Whilst the impending departure from the EU of one of the most powerful Eurosceptic Member States might weaken this resistance, ${ }^{97}$ in the absence of international convergence on what should be included in a tax base and what should be the (minimum) tax rate, it is unlikely that the EU will take any large-scale tax harmonising action internally. The lack of legislative bases and the need for unanimity certainly do not help. Of course, if the European Commission ever manages to convince all Member States (or at least enough Member States to activate the enhanced cooperation mechanism) to adopt the CCTB, this could pave the way for more uniformity of corporate tax rates - or at least the introduction of a minimum corporate tax rate.

Arguably, the European Commission might not even need to await the introduction of the CCTB in order to politically manoeuvre a uniform tax rate or a minimum tax rate. In the past, there were reports that the European Commission would propose the abandonment of the unanimity rule on tax issues so as to promote more efficient law-making. ${ }^{98}$ In a letter of intent ${ }^{99}$ accompanying his annual State of the Union address, ${ }^{100}$ Jean-Claude Juncker stated that the European Commission would in 2019 issue a communication identifying areas in the taxation field for which qualified majority voting could be introduced. Indeed, in January 2019, the Commission published a bold proposal $^{101}$ to move away from unanimity to qualified majority voting in the

${ }^{97}$ Ironically, the UK is considering introducing unilateral rules for the taxation of the digital economy. See, for example, the UK Treasury's Corporate Tax and the Digital Economy: Position Paper (November 2017) and Corporate Tax and the Digital Economy: Position Paper Update (March 2018) <https://www.gov.uk/government/consultations/corporate-tax-and-thedigital-economy-position-paper>.

${ }^{98}$ Elodie Lamer, 'EU to Identify Tax Matters for Qualified Majority Voting' (2018) 91 (17 September 2018) Tax Notes International 1250.

${ }_{99}$ Jean-Claude Juncker and Frans Timmermans, State of the Union 2018. Letter of Intent to President Antonio Tajani and to Chancellor Sebastian Kurz (12 September 2018) $\langle$ https://ec.europa.eu/commission/sites/beta-political/files/soteu2018-letter-of-intent_en.pdf>.

100 Jean-Claude Juncker, 'State of the Union 2018. The Hour of European Sovereignty' European Commission (Speech, 12 September 2018) <https://ec.europa.eu/commission/news/stateunion-2018-hour-european-sovereignty-2018-sep-12_en>.

${ }^{101}$ Commission Communication, 'Towards a More Efficient and Democratic Decision Making in EU Tax Policy' COM (2019) 8 final, 15/1/2019. Indicatively, in this Communication it was noted that '[f]or the Commission, the question is no longer whether there is a need to move away from unanimity in taxation, but rather how and when to do it': at 11. 
tax area. The Commission proposed to move to qualified majority voting through a very ambitious four stage roadmap, which would eventually encompass many areas of fiscal policy. Whilst this matter is highly political, in the current political context a complete abandonment of Member States' fiscal veto seems rather unlikely. However, nothing is impossible when it comes to the EU.

\section{EU ANTI-ABUSE RULES}

Most corporate tax systems contain rules which prevent their abuse. Often, the more sophisticated the corporate tax system, the more sophisticated and complex the anti-abuse rules of the system are likely to be. As the EU does not have a harmonised and comprehensive corporate tax system other than the de minimis and ad hoc rules briefly discussed in Part I, one would not expect to find any self-standing anti-abuse rules other than those encompassed in these de minimis rules. Nevertheless, the European Commission seized on the political momentum generated by the OECD/G20's BEPS project and its aftermath, and produced a proposal for a wide range of common anti-abuse rules which was eventually approved in Council. This was the Anti-Tax Avoidance Directive ('ATAD').

The $A T A D$ was part of the European Commission's Anti-Tax Avoidance Package, which was published in January 2016. ${ }^{102}$ This Package emanated from the European Commission's ambitious agenda for a fairer, simpler and more effective corporate tax system in the EU. This approach to anti-abuse issues was foreshadowed in its Action Plan for a Fair and Efficient Corporate Tax System, which was published in June 2015, a few months before the OECD/G20 BEPS Final Reports were themselves published. ${ }^{103}$ The Action Plan had been released as a Commission Communication ${ }^{104}$ and was intended to improve the corporate tax environment in the European Union, making it fairer, more efficient and more growth-friendly. The key actions included a strategy to relaunch the Common Consolidated Corporate Tax Base (as explained in the previous Part of this article) and a framework for effective taxation where profits are generated, largely premised on the OECD/G20's

\footnotetext{
102 European Commission, Anti Tax Avoidance Package (Web Page, January 2016) $<$ https://ec.europa.eu/taxation_customs/business/company-tax/anti-tax-avoidance-package _en>. See analysis in Christiana HJI Panayi, 'The Europeanisation of Good Tax Governance' (2018) 36(1) Yearbook of European Law 442, part III(C) ('Europeanisation of Good Tax Governance').

${ }^{103}$ BEPs Action Plan (n 38).

104 'A Fair and Efficient Corporate Tax System' (n 41).
} 
BEPS conclusions. It was not a major surprise, therefore, when the Anti-Tax Avoidance Package was published early in 2016.

This Package consisted of seven parts: a proposed Anti-Tax Avoidance Directive; ${ }^{105}$ a Recommendation on the implementation of the BEPS recommendations on tax treaty abuse and on permanent establishments; ${ }^{106}$ a proposed amendment to the Directive on Administrative Cooperation to include mandatory country-by-country reporting requirements; ${ }^{107}$ a general policy Communication; ${ }^{108}$ a Communication on an EU external strategy for effective taxation; ${ }^{109}$ a European Commission Staff Working Document; ${ }^{110}$ and a Study on Aggressive Tax Planning. ${ }^{111}$

In the initial ATAD proposal, ${ }^{112}$ the European Commission proposed action in three areas covered by the BEPS proposals, namely: hybrid mismatches, ${ }^{113}$ interest restrictions, ${ }^{114}$ and Controlled Foreign Corporation ('CFC') rules. ${ }^{115}$ The European Commission also proposed action in three areas not covered by the BEPS Action plan, namely: a general anti-abuse rule ('GAAR'), a switchover clause and rules to tackle exit taxation. Political agreement on the

\footnotetext{
105 European Commission, Proposal for a Council Directive Laying Down Rules Against Tax Avoidance Practices that Directly Affect the Functioning of the Internal Market, COM/2016/026 final, 28 January 2016.

${ }^{106}$ European Commission, Commission Recommendation of 28.1.2016 on the Implementation of Measures Against Tax Treaty Abuse, C(2016) 271 final, 28 January 2016.

${ }^{107}$ European Commission, Proposal for a Council Directive Amending Directive 2011/16/EU as regards Mandatory Automatic Exchange of Information in the Field of Taxation, COM/2016/025 final - 2016/010 (CNS), 28 January 2016.

${ }^{108}$ European Commission, Commission Communication, Anti-Tax Avoidance Package: Next Steps towards Delivering Effective Taxation and Greater Tax Transparency in the EU, $\operatorname{COM}(2016) 23$ final, 28 January 2016.

${ }^{109}$ European Commission, Communication from the Commission to the European Parliament and the Council on an External Strategy for Effective Taxation, COM(2016) 24 final, 28 January 2018 ('External Strategy Communication').

${ }^{110}$ European Commission, Commission Staff Working Document, Accompanying the document Communication from the Commission to the European Parliament and the Council - Anti Tax Avoidance Package: Next Steps towards Delivering Effective Taxation and Greater Tax Transparency in the EU, SWD/2016/06 final, 28 January 2016.

${ }^{111}$ Henrik Meldgaard et al, Study on Structures of Aggressive Tax Planning and Indicators, Final Report (Taxation Papers, Working Paper No 61, European Commission, 23 December 2015).

${ }^{112}$ European Commission, Proposal for a Council Directive Laying Down Rules against Tax Avoidance Practices that Directly Affect the Functioning of the Internal Market, $\operatorname{COM(2016)~}$ 26 final, 28 January 2016.

${ }^{113}$ BEPS Action Plan (n 38) Action 2.

${ }^{114}$ Ibid Action 4.

${ }^{115}$ Ibid Action 3.
} 
Directive was finally reached on 17 June 2016, after several amendments and the deletion of the switch-over clause from the Directive. On 12 July 2016, the Council of the European Union formally adopted the new version of the ATAD. ${ }^{116}$

Pursuant to the $A T A D$, all taxpayers that are subject to corporate tax in a Member State, including subsidiaries of companies based in third countries will, from the date that the provisions of the Directive become effective, ${ }^{117}$ be scrutinised on the basis of the five anti-abuse rules. ${ }^{118}$ The $A T A D$ now provides for:

a) uniform (but de minimis) interest limitation rules to prevent multinational groups from artificially shifting their debt to jurisdictions with more generous deductibility rules;

b) exit taxation rules to ensure that, where a taxpayer moves assets or its tax residence out of the tax jurisdiction of a State, that State taxes the economic value of any capital gain created in its territory even though that gain has not yet been realised at the time of the exit;

c) a GAAR to cover gaps that may exist in Member State's specific antiabuse rules;

d) CFC rules to prevent the shifting of large amounts of profits towards controlled subsidiaries in low-tax jurisdictions; and

e) rules on hybrid mismatches to prevent corporate taxpayers from taking advantage of disparities between national tax systems in order to reduce their overall tax liability.

${ }^{116}$ Council Directive 2016/1164 of 12 July 2016 Laying Down Rules against Tax Avoidance Practices that Directly Affect the Functioning of the Internal Market [2016] OJ L 193/1 ('ATAD').

117 Technically, Member States had until 31 December 2018 to transpose the ATAD into their national laws and regulations, except for the exit taxation rules, for which they have until 31 December 2019. Member States that have targeted rules that are equally effective to the interest limitation rules may apply them until the OECD reaches an agreement on a minimum standard, or until 1 January 2024 at the latest.

${ }^{118} A T A D$ (n 116) art 1. 
The scope of this latter provision was further broadened to include provisions against hybrid mismatch arrangements with third countries. ${ }^{119}$

Overall, most of these provisions seem to be out of place, and rather paradoxical given the framework into which they were transplanted. For example, whilst there are no harmonised rules (under EU law) as to what gains should be taxable in a Member State and what the tax rate should be, there is a provision to ensure that if such gains are taxable in the Member State of origin (of the taxpayer), then part of the economic value of the gain should be awarded to that Member State when the taxpayer becomes non-resident, even if that gain has not yet been realised at that point. ${ }^{120}$ Similarly, whilst EU law does not provide for specific anti-avoidance rules other than the $A T A D$ rules and those arising from the Directives, nevertheless, a general anti-avoidance rule ensures that no gaps are left by domestic anti-abuse rules. Furthermore, whilst there is as yet no EU requirement for a minimum corporate tax rate, there are now provisions which effectively penalise a company for owning and controlling subsidiaries in lowtax jurisdictions. Finally, whilst there are no common corporate tax rules other than those set out in the directives discussed above, nevertheless benefiting from mismatches in the national tax legislations of Member States leading to double non-taxation is now against EU law.

There is also a further, more general criticism. If the EU does not have the competence to harmonise direct tax legislation (including corporate tax legislation) and is restricted to ad hoc targeted solutions, then how can it harmonise the exception to these otherwise unharmonised rules? Arguably, as far as the $A T A D$ was concerned, competence was conceded as all Member

\footnotetext{
119 This was following a further proposal by the Commission. See European Commission, Commission Staff Working Document Accompanying the Document Proposal for a Council Directive Amending Directive (EU) 2016/1164 as Regards Hybrid Mismatches with Third Countries, $\operatorname{COM(2016)~} 687$ final, 25 October 2016. Apart from closing the loopholes as a result of the rules not being applied to third country taxpayers, one important reason for this proposal was to align the rules with the corresponding provisions in the CCTB proposal. Under this proposal, the hybrid provisions would not only apply to mismatch arrangements within the EU, but also to mismatches arising in relation to third countries. The hybrid provisions would also deal with mismatches involving permanent establishments, imported mismatches, hybrid transfers and dual resident mismatches. This proposed amendment to the ATAD (also often referred to as ATAD II) was adopted in May 2017. Member States have until 31 December 2019 to adopt rules to implement $A T A D$ II. In line with the compromise agreement, the adopted ATAD II Directive includes a carve-out option through to 31 December 2022, for hybrid regulatory capital in the banking sector, and a carve-out for financial traders involving hybrid transfers made in the ordinary course of business.

${ }^{120}$ Under $A T A D$ (n 1166) art 5, when a taxpayer becomes non-resident, then the taxpayer is subject to tax at an amount equal to the market value of the transferred assets, at the time of exit of the assets. The taxpayer has the option to pay this pre-determined amount in five yearly instalments. There are no provisions for reductions in value.
} 
States agreed to the proposal, though some did so more reluctantly than others. It is, however, unfortunate that EU law was the medium used to transpose into national legislation BEPS-related measures, which were quite extrinsic to the EU legal system up to that point. As is shown below, this potentially causes further uncertainties in this area, as some of the legislative provisions are at odds with established case law of the CJEU.

In addition to these targeted anti-abuse rules, anti-abuse clauses long existed in the Parent-Subsidiary Directive, the Merger Directive and the Interest and Royalties Directive. ${ }^{121}$ The aim of these clauses is to prevent the forms of relief provided under the Directives from being abused. For example, the ParentSubsidiary Directive and the Interest and Royalties Directive allow domestic or agreement-based provisions required for the prevention of fraud or abuse. ${ }^{122}$ The Parent-Subsidiary Directive also contains a provision which prevents relief from being granted in situations of mismatches in the tax treatment of profit distributions which would lead to double non-taxation. ${ }^{123}$ Furthermore, under the recently adopted Tax Dispute Resolution Directive, a Member State may deny access to a dispute resolution procedure in cases where penalties were imposed in that Member State in relation to adjusted income or capital for tax fraud, wilful default and gross negligence. ${ }^{124}$

It should be emphasised that, up until the $A T A D$ 's anti-abuse rules were introduced, the anti-abuse provisions of the relevant directives constituted the only EU anti-abuse legislation existing at the time. In fact, up until very recently, the focus of attention of most EU institutions and, generally speaking, the European Commission and the CJEU, was on whether Member State antiabuse rules were compatible with fundamental freedoms and the nondiscrimination principle in general. The high-water mark of this approach was the CJEU's judgment in the Cadbury Schweppes case. ${ }^{125}$

This was the first important case that dealt with CFC regimes, and the focus was on the UK rules existing at the time. According to the legislation, a resident company was subject to corporation tax on its worldwide profits, which, at the time, included the profits of a foreign branch ${ }^{126}$ but not the profits of a foreign

\footnotetext{
${ }^{121}$ See Parent-Subsidiary Directive (n 23) art 1(2); Interest and Royalties Directive (n 24) art 5; Merger Directive (n 22) art 15.

${ }^{122}$ See Parent-Subsidiary Directive (n 23) art 1(2); Interest and Royalties Directive (n 24) art 5.

${ }^{123}$ See Parent-Subsidiary Directive (n 23) art 4(1)(a).

${ }^{124}$ Tax Dispute Resolution Directive (n 27) art 16(6).

125 Cadbury Schweppes and Cadbury Schweppes Overseas (C-196/04) [2006] ECR I-07995

('Cadbury Schweppes').

${ }^{126}$ Under the current UK regime, branches can now be exempt.
} 
subsidiary. Broadly, a UK parent company was taxed on the profits of the foreign subsidiary only when they were distributed to it as dividends. When the UK CFC legislation was triggered, the profits of a foreign subsidiary were attributed to the UK parent company at the time at which the profits arose and were taxed, with a credit for the foreign tax paid by the subsidiary. If the subsidiary subsequently distributed a dividend, this tax could be credited against the tax payable by the parent company on the dividend.

In this case, Cadbury Schweppes, a UK company, indirectly held $100 \%$ of the shares of two Irish subsidiaries. These subsidiaries were subject to a $10 \%$ corporate tax rate under the International Financial Services Centre regime in Dublin, ${ }^{127}$ which was lower than the UK tax rate. As none of the exemptions under the UK CFC rules applied, Cadbury Schweppes was taxed by the UK tax authorities on the profits of its Irish subsidiaries. The case was eventually referred to the CJEU.

The CJEU held that the UK legislation had to be examined in light of the freedom of establishment only. ${ }^{128}$ It was found that the UK CFC rules restricted the freedom of establishment because the profits of a controlled company were only attributed to the UK parent company when this controlled company was incorporated in a low-tax Member State, within the meaning of the UK CFC rules. Profits were not attributed to the UK parent if the controlled company was a UK resident. ${ }^{129}$ Such a difference of treatment dissuaded UK-resident companies from establishing, acquiring or maintaining a subsidiary in a Member State with such a lower level of taxation and therefore constituted a restriction on the freedom of establishment. ${ }^{130}$

This restriction was justified on the basis of prevention of tax avoidance and evasion. It was emphasised that the mere fact that a resident company established a secondary establishment such as a subsidiary in another Member State could not justify a general presumption of tax evasion. ${ }^{131}$ A national measure restricting the freedom of establishment could only be justified when

\footnotetext{
127 This regime has now been phased out.

${ }^{128}$ It was explained that the UK CFC rules applied to resident companies that had a controlling holding in their subsidiary established outside the United Kingdom. This gave the resident company definite influence over the subsidiary's decisions and allowed the resident companies to determine the subsidiary's activities. Although the rules had restrictive effects on the free movement of services and the free movement of capital, such effects were an unavoidable consequence of any restriction on the freedom of establishment. Cadbury Schweppes (n 125) [31]-[33].

${ }^{129}$ Ibid [44].

${ }^{130}$ Ibid [45].

${ }^{131}$ Ibid [50].
} 
it specifically related to "wholly artificial arrangements which do not reflect economic reality, with a view to escaping the tax normally due on the profits generated by activities carried out on national territory'. ${ }^{132}$

Although the UK CFC rules were suitable for the attainment of this objective, they also had to be proportional. The CFC rules had to exclude from their scope situations where, despite the existence of tax motives, the arrangements reflected economic reality.

This reasoning was followed in numerous cases. ${ }^{133}$ Later cases emphasised that, as regards proportionality, the taxpayer must be given the opportunity, without being subject to undue administrative constraints, to provide evidence of any commercial justification for that transaction. ${ }^{134}$ Also, where there is recharacterisation of an interest payment, this re-characterisation should be limited to the proportion of that interest which exceeds the arm's length amount. $^{135}$

What is evident from this brief exposition is that, hitherto, in most cases litigated at the CJEU, the emphasis was mostly on the compatibility of national anti-abuse provisions with EU law and not the protection of the tax bases of Member States. Very importantly, this appears to be the approach even in the post-BEPS era, although there are calls for the CJEU to be more attuned to the risk of tax avoidance or double non-taxation. ${ }^{136}$ In recent cases dealing with the anti-abuse provisions of the Parent-Subsidiary Directive, it was reiterated that such provisions should still be targeted against wholly artificial arrangements and should not be too broadly phrased. In the Eqiom \& Enka case, ${ }^{137}$ it was

\footnotetext{
${ }^{132}$ Ibid [55].

${ }^{133}$ See HJI Panayi, EU Corporate Tax Law (n 4) ch 8. See also Christiana HJI Panayi, 'Cadbury Schweppes and Cadbury Schweppes Overseas (2006): CFC Rules Under EU Tax Law' in John Snape and Dominic de Cogan (eds), Landmark Cases in Revenue Law (Hart Publishing, 2019) 417; Christiana HJI Panayi, 'The ATAD's CFC Rule and Its Impact on the Existing Regimes of EU Member States' in Pasquale Pistone and Dennis Weber (eds), The Implementation of Anti-BEPS Rules in the EU: A Comprehensive Study (IBFD, 2018) 355.

${ }^{134}$ Test Claimants in the Thin Cap Group Litigation v Commissioners of Inland Revenue (C524/04) [2007] ECR I-2107.

135 Ibid.

${ }^{136}$ See $N N A / S v$ Skatteministeriet (CJEU, C-28/17, 4 July 2018) (' $N N A / S$ '), where Advocate General Campos argued that the restrictive tax rule was justified by the prevention of double deduction of losses, a justification that was especially pertinent following the OECD BEPS project and art 2 of the ATAD Directive on hybrid mismatches. See NN A/S [65]-[73]. Whilst the CJEU agreed on the issue of justification, it did not refer to the BEPS project or any other instruments.

${ }^{137}$ Eqiom SAS and Enka SA v Ministre des Finances et des Comptes publics (CJEU, C-6/16, 7 September 2017).
} 
emphasised that there cannot be an initial presumption of abuse where an EU parent company was controlled by shareholders in third states. A similar conclusion was reached in the Diester Holding case. ${ }^{138}$

Where does this discord leave us as far as a harmonised corporate tax base is concerned? Certainly, anti-abuse rules are crucial to any system as they protect the corporate tax base. However, the co-existence of the current ad hoc antiabuse rules (whether as part of other directives or as substantive provisions in the $A T A D$ ) with the principles derived from the case law of the CJEU appears to be contradictory. The author has argued elsewhere that some of the provisions of the ATAD may not be aligned with the case law of the CJEU. ${ }^{139}$ Broadly, the scope of the anti-abuse rules in the directives (and especially in the $A T A D$ ) tends to be rather broad, placing the burden of proof on taxpayers. However, case law suggests that national anti-abuse rules should be targeted against wholly artificial arrangements, thus shifting the burden of proof onto the tax authorities to show that this is the case. In fact, as part of the proportionality assessment, the case law requires that taxpayers be given the opportunity to prove the commerciality of the arrangement. These contradictory positions are not conducive to legal certainty. Rather, they jeopardise any future attempts to streamline the EU's corporate tax system.

\section{EU Transfer Pricing Rules?}

Apart from the above legislation on anti-abuse rules and the, often contradictory, relevant case law, there is a combination of soft law and hard law for the regulation of transfer pricing. For a long time, the Arbitration Convention was a key instrument in this area. This was a convention signed by all Member States, dealing with the elimination of double taxation arising from transfer pricing adjustments and the settlement disputes between Member State competent authorities on the basis of the arm's length principle. ${ }^{140}$ Guidance was given on the implementation of the Convention through soft law instruments, ${ }^{141}$ many of which were produced by the European Commission's

138 See Deister Holding AG v Bundeszentralamt für Steuern (CJEU, C-504/16, 20 December 2017).

${ }^{139}$ HJI Panayi, Advanced Issues (n 21) ch 7.

${ }^{140}$ Convention on the Elimination of Double Taxation in Connection with the Adjustment of Profits of Associated Enterprises - Final Act [1990] OJ L 225/10.

${ }^{141}$ For example, the Code of Conduct for the effective implementation of the EU Arbitration Convention. This Code of Conduct seeks to ensure a more effective and uniform application of the Arbitration Convention by all Member States. Also see Revised Code of Conduct for the Effective Implementation of the Convention on the Elimination of Double Taxation in Connection with the Adjustment of Profits of Associated Enterprises [2009] OJ C 322/1. See 
Joint Transfer Pricing Forum. ${ }^{142}$ The new Tax Dispute Resolution Directive Convention does not officially replace the Arbitration Convention but certainly provides a more efficient route for taxpayers to take in resolving their tax disputes with competent authorities.

So far, the CJEU has considered transfer pricing issues in two cases referred to it. Both cases were decided in a rather conservative way. In the first case dealing with transfer pricing rules, the $S G I$ case, ${ }^{143}$ it was questioned whether the Belgian rules were compatible with the non-discrimination provision, the freedom of establishment and the free movement of capital rules.

Here, a Belgian holding company, Société de Gestion Industrielle SA (SGI), made an interest-free loan to a French subsidiary and paid management expenses to a Luxembourg corporate shareholder, who was also the director and managing director of SGI. For the interest-free loan, the Belgian tax authorities added a notional interest payment to SGI's tax base and they refused to allow a business expense deduction for the management fees. SGI challenged these assessments and the case was referred to the CJEU.

The CJEU found that the Belgian legislation restricted the freedom of establishment ${ }^{144}$ but it was justified on the basis that it preserved the balanced

\footnotetext{
also the Code of Conduct on Transfer Pricing Documentation for Associated Enterprises in the EU, OJ C 176, 28.7.2006, 1-7.

${ }^{142}$ See European Commission, Report on the Application of the Profit Split Method within the EU (March 2019) JTPF/002/2019/EN; European Commission, Report on the Use of Comparables in the EU (2017) JTPF/007/2016/FINAL/EN; Deloitte, Directorate-General for Taxation and Customs Union (European Commission), Study on Comparable Data Used for Transfer Pricing in the EU: Final Report (19 December 2016) <https://publications.europa.eu/en/publication-detail/-/publication/d16d2635-c685-11e6-a6db01aa75ed71a1>; Deloitte, Directorate-General for Taxation and Customs Union (European Commission) Study on the Application of Economic Valuation Techniques for Determining Transfer Prices of Cross Border Transactions between Members of Multinational Enterprise Groups in the EU: Final Report (19 December 2016) <https://publications.europa.eu/en/publication-detail/-/publication/e7dbd290-c682-11e6-a6db01aa75ed71a1/language-en/format-PDF/source-search>; European Parliament, Committee on Industry, Research and Energy, Report on Small and Medium Size Enterprises (SMEs): Competitiveness and Business Opportunities (28 September 2012) 2012/2042(INI); European Commission, Draft Report on Cost Contribution Arrangements on Services Not Creating Intangible Property (May 2012) JTPF/008/REV1/2012/EN; European Commission, Report on Transfer Pricing Risk Management (June 2013) JTPF/007/FINAL/2013/EN; European Commission, Final Report on Secondary Adjustments (2012) JTPF/017/FINAL/2012/EN; European Commission, Report on Compensating Adjustments (2013) JTPF/009/FINAL/2013/EN.

${ }^{143}$ Société de Gestion Industrielle (SGI) v État belge [2010] OJ C 63/8 ('SGI’).

${ }^{144}$ Ibid [55].
} 
allocation of taxing powers between Member States. ${ }^{145}$ The CJEU also found the legislation to be justified on the basis of preventing tax avoidance, even though the national legislation was not specifically designed to counteract purely artificial arrangements. ${ }^{146}$ In the judgment, the Court used inconsistent terms to identify tax avoidance. ${ }^{147}$

In any case, for the legislation to be proportional, two grounds had to be satisfied. First, on each occasion where there was a suspicion that a transaction went beyond what the companies would have agreed under fully competitive conditions, the taxpayer had to be given an opportunity, without being subject to undue administrative constraints, to provide evidence of any commercial justification that there may have been for that transaction. ${ }^{148}$ Secondly, where the consideration of such elements led to the conclusion that the transaction went beyond what the companies would have agreed under fully competitive conditions, the corrective tax measure had to be confined to the part which exceeded what would have been agreed if the companies did not have a relationship of interdependence. ${ }^{149}$ The CJEU concluded that it was for the referring court to decide whether the Belgian legislation went beyond what was necessary to attain the objectives pursued by the legislation, taken together. ${ }^{150}$

In another recent case on transfer pricing, the Hornbach-Baumarkt case, ${ }^{151}$ it was questioned whether the German transfer pricing legislation was compatible with the freedom of establishment. The legislation applied only to cross-border situations and did not allow the taxpayer to rely for justification on commercial reasons resulting from its status as a shareholder of the foreign subsidiary. In this case, a German parent company had given guarantees and letters of comfort to banks with respect to loans made to foreign subsidiaries, but without requiring any payment or consideration. The German tax authorities adjusted

\footnotetext{
${ }^{145}$ Ibid [60]-[64]. As noted, giving companies the right to elect to have their losses or profits taken into account in their Member State or in another Member State could seriously undermine a balanced allocation of the power to impose taxes between the Member States, since the tax base would be increased in one of the Member States, and reduced in the other, by the amount of the losses or profits transferred.

${ }^{146}$ Ibid [66].

147 The CJEU initially used the term 'wholly artificial arrangements' (ibid [65]), then 'purely artificial arrangements' (at [66]) and later just 'artificial arrangements' (at [67]). See Opinion Statement of the CFE on the case law of the European Court of Justice on transfer pricing related to loans (at [10]).

${ }^{148}$ Ibid [71].

${ }^{149}$ Ibid [72].

${ }^{150}$ Ibid [75].

${ }^{151}$ Hornbach-Baumarkt-AG v Finanzamt Landau (CJEU, C-382/16, 31 May 2018) ('HornbachBaumarkt').
} 
the profits of the parent company upwards and the parent company challenged this decision. The case was eventually referred to the CJEU which concluded that there was no incompatibility.

The CJEU found that the transfer pricing legislation constituted a restriction to the freedom of establishment. ${ }^{152}$ This restriction was justified by the need to preserve the balanced allocation of taxing rights between the Member States, provided that the transfer pricing legislation was aimed at preventing profit shifting via transactions that were not in accordance with market conditions. The CJEU did not consider whether the restriction was justified on the basis of preventing tax avoidance, as no such argument had been advanced. ${ }^{153}$

The CJEU went on to examine the proportionality of the German transfer pricing legislation and to clarify the meaning of the concept of 'commercial justification'. It was questioned whether this concept included economic reasons resulting from the very existence of a relationship of interdependence between the parent company and its subsidiaries which were resident in another Member State. ${ }^{154}$ The CJEU found that there may be a commercial justification by virtue of the fact that the taxpayer was a shareholder in the foreign group companies, which would justify the conclusion of the transaction under nonarm's length terms. ${ }^{155}$ As the gratuitous granting of comfort letters containing a guarantee statement could be explained by the economic interest of the shareholder in the financial success of the foreign group subsidiaries, this could be sufficient commercial justification. This being the case, the German legislation did not go beyond what was necessary to achieve the objective pursued, to the extent that 'the authorities responsible for the enforcement of that legislation afford the resident taxpayer the opportunity to prove that the terms were agreed on for commercial reasons which could result from its status as a shareholder in the non-resident company, which is a matter for the referring court to assess'. 156

This is a very important decision. Contrary to the advice of the Advocate General, the CJEU did not rely on tax avoidance or profit shifting reasons to justify the legislation. Rather, its acceptance of commercial justification and what that encompasses could pave the way for what the Advocate General

\footnotetext{
${ }^{152}$ Ibid [35].

${ }^{153}$ As pointed out by the CJEU, the German government neither identified a wholly artificial arrangement, within the meaning of the case law, nor a desire on the part of the applicant in the main proceedings to reduce its taxable profit in Germany: ibid [55].

${ }^{154}$ Ibid [51].

${ }^{155}$ Ibid [56].

${ }^{156}$ Ibid [58].
} 
warned to be 'a blunt and full exclusion of any business transactions with subsidiaries from the application of the [arm's length] principle, because a parent will always have interest in seeing its subsidiary prosper'. ${ }^{157}$

By not insisting on wholly artificial arrangements, both cases seem to confirm that the CJEU is taking a slightly different approach from that taken under other anti-abuse rules. Perhaps this is understandable, as there is much more developed international soft law - or at least international convergence on some concepts - which is set out in the OECD's Transfer Pricing Guidelines. However, this does not mean that the CJEU will eschew any discussion or challenge over some provisions of, or practices under, national transfer pricing regimes, even if those provisions or practices emanate from established principles under the OECD's Transfer Pricing Guidelines. It would seem that this is encouraged by the European Commission, if one considers the recent state aid challenges over the transfer pricing practices of some Member States.

The prohibition on state aid ${ }^{158}$ is another EU treaty provision that has had a huge impact on transfer pricing. This provision applies when aid, in the sense of a benefit or advantage, is granted by a Member State or through Member State resources. The aid must favour certain undertakings or the production of certain goods (the 'selectivity' principle), it must distort or threaten to distort competition, and must be capable of affecting trade between Member States.

The state aid prohibition has become very important in the tax field. Measures that relieve the recipients of charges that are normally borne from their budgets, ${ }^{159}$ such as reductions in the tax base, total or partial reduction in the amount of tax (exemption or tax credit) payable, and deferment, cancellation or even special rescheduling of tax debts, are, according to the European Commission, examples of state aid. ${ }^{160}$ Such measures mitigate the charge that would normally be recoverable from the undertaking. A company may be affected by the state aid prohibition whether it is the recipient of aid or the competitor of such a company. ${ }^{161}$ Aid given to a company may have to be repaid

\footnotetext{
157 Ibid, opinion [113]

158 TFEU (n 2) art 107.

${ }^{159}$ Commission Notice on the Application of the State Aid Rules to Measures Relating to Direct Business Taxation [1998] OJ C384/3 3-9 [9] ('1998 Notice'). For a commentary on the 1998 Notice, see European Commission, Report on the Implementation of the Commission Notice on the Application of the State Aid Rules to Measures Relating to Direct Business Taxation, COM(2004) 434, 9 February 2004.

1601998 Notice (n 159) [10].

161 Recently, a direct action against a Commission decision brought by competitors of the beneficiaries of a State aid measure was admitted for the first time. See Scuola Elementare
} 
if it is unlawful or has not been properly notified or approved by the European Commission. If repayment is demanded, the taxpayer will have to reimburse the full amount of the financial benefit within a period of four months, including interest, for up to a maximum of 10 years prior to the start of an investigation. No recovery is necessary when the unlawful aid was paid more than 10 years before the European Commission's decision.

The European Commission has a pivotal role in the application of the state aid regime. ${ }^{162}$ It constantly reviews existing aids offered by Member States. ${ }^{163}$ Furthermore, Member States are required to notify the European Commission as to any plans to grant or alter state aid. ${ }^{164}$ The European Commission may also ask the CJEU to order a Member State to recover illegal state aid. ${ }^{165}$

In the last few years, the state aid prohibition has been used by the European Commission to challenge transfer pricing practices of Member States; they were alleged to have selectively conferred advantages on some multinationals. The first high-profile investigations were launched by the European Commission in the summer of 2014, to examine whether certain multinational companies had received transfer pricing tax rulings which had led to significant tax reductions (or no taxation at all) in violation of the state aid rules. The MNEs and jurisdictions involved were Apple in Ireland, Starbucks in the Netherlands and Fiat and Amazon in Luxembourg. Many more cases followed. Some cases are still being investigated by the European Commission, but other cases are under appeal in the CJEU after the European Commission delivered its decisions.

It is beyond the scope of this article to examine the specific details of all the investigations. Broadly, the crux of the matter in most of the cases investigated was whether the tax rulings given by the relevant Member States allowed the MNEs to depart from market conditions in setting the commercial conditions (and pricing) of intra-group transactions, which led to the renunciation of tax revenue by Member States and as a corollary of Member State resources. The

\footnotetext{
Maria Montessori Srl v European Commission (CJEU, Joined cases C-622/16 P to C-624/16 P, 6 November 2018).

${ }^{162}$ National courts play an equally important role in applying art 107 of the TFEU in conjunction with art 108(3) of the TFEU (ex-Art 88(3) EC). See Notice on Cooperation between National Courts and the Commission in the State Aid Field [1995] OJ C312/07, replaced by Notice on the Enforcement of State Aid Law by National Courts [2009] OJ C85/1.

${ }^{163}$ See TFEU (n 2) art 108(1). Aid may be regarded as existing aid because of Court of Justice case law and Council Regulation (EC) No 659/1999 of 22 March 1999 Laying Down Detailed Rules for the Application of Article 93 of the EC Treaty [1999] OJ L 83/1, art 1.

164 TFEU (n 2) art 108.

${ }^{165}$ See, eg, Commission v Spain (CJEU, C-184/11, 13 May 2014).
} 
premise of the European Commission's opening decisions in the initial cases seemed to be that the existence of advantage and selectivity was satisfied when the arm's length principle of the OECD Model Tax Convention was not complied with. ${ }^{166}$ In later decisions, the European Commission refined its reasoning by finding that the impugned arrangements derogated from normal practices under domestic law and the arm's length principle as encompassed under EU state aid rules. As stated many times in the European Commission's recent decisions, 'the arm's-length principle therefore necessarily forms part of the European Commission's assessment under article 107(1)'. ${ }^{167}$ In other words, the European Commission considered that the arm's length principle was neither the one derived from article 9 of the OECD Model Tax Convention, nor the one under domestic rules, but rather a general principle under article 107(1) of the TFEU that prevented distortion of competition.

At the time of writing, the CJEU has not yet delivered judgment on any of the cases under appeal. ${ }^{168}$ Nevertheless, on the basis of established ${ }^{169}$ and recent ${ }^{170}$ case law in this area, it seems that, even though Member States are thought to have retained competence in regulating their corporate tax systems, in fact they are very restricted as to what type of tax incentives they can give - whether

\footnotetext{
${ }^{166}$ See analysis in HJI Panayi, Advanced Issues (n 21) ch 7.

167 See, eg, Commission Decision (EU) 2016/1699 of 11 January 2016 on the Excess Profit Exemption State Aid Scheme [2016] OJ L 260/61) [150]; Commission Decision (EU) 2017/502 of 21 October 2015 on State Aid [2017] OJ L 83/38) [264]; Commission Decision (EU) 2016/2326 of 21 October 2015 on State Aid [2016] OJ L 351/1) [228]. For commentary, see Ruth Bonnici, 'The European Commission's Arm's Length Standard: Relationship and Compatibility with the Arm's Length Principle under Transfer Pricing' (2019) 26(1) International Transfer Pricing Journal 1.

168 On 14 February 2019, the General Court annulled the Commission's decision in the Belgian excess profits case (Belgium v Commission (Court of Justice of the European Union, T-131/16 and T-263//16, 14 February 2019) as it failed to demonstrate why the selected sample was representative. The General Court found that a more detailed review was required. As the General Court did not invalidate the Commission's substantive interpretation of the State aid rules, but rather challenged the methodology of assessment and the classification of the aid as a 'scheme', this ruling might not have an impact on the currently pending cases and the Commission's interpretation of the arm's length principle is still to be examined. This case has recently been appealed by the European Commission in Commission v Belgium and Magnetrol International Case C-337/19 P. See HJI Panayi, 'European Community Tax Law' (n 28) ch $19[5 \mathrm{~A}]$.

${ }^{169}$ See HJI Panayi, Advanced Issues (n 21) ch 7, and the case law discussed therein.

${ }^{170}$ See European Commission v World Duty Free Group SA (CJEU, C-20/15 P, 21 December 2016); Asociación Nacional de Grandes Empresas de Distribución (ANGED) v Diputación General de Aragón (CJEU, C-236/16 and C-237/16, 21 June 2012); Commission v Spain (CJEU, C-128/16P, 24 November 2011); Hungary v European Commission (CJEU, Case T20/17, 27 June 2019). See analysis in HJI Panayi, 'European Community Tax Law' (n 28) ch $19[5 \mathrm{C}]$.
} 
through transfer pricing rulings, or advance pricing agreements, or the tax system as a whole. As noted earlier, basic concepts of transfer pricing, and especially the arm's length principle, remain in the realm of soft law, which is mainly encapsulated in the OECD Model Tax Convention and the OECD Transfer Pricing Guidelines. The case law discussed in this Part of the article shows some reluctance by the CJEU to interfere with this soft law. This case law is, however, rather limited and based on fundamental freedoms such as the freedom of establishment, the theoretical underpinnings of which are very different. If the arm's length principle is eventually interpreted by the CJEU as being encompassed in the TFEU's state aid prohibition, this could mean that EU law will, in the future, have a decisive role in what is and what is not to be considered an arm's length arrangement. In other words, there may well be significant EU interference in the transfer pricing regimes of Member States in the end.

\section{Is There AN EU TAX Administration?}

All corporate tax systems have to be administered or at least overseen by a central tax authority.

As shown in this article, the development of a body of corporate tax law in the European Union has been rather random and at times contradictory, the product of often opportunistic reactions to certain political exigencies rather than a carefully constructed system. Therefore, the lack of some form of central EU tax administration is hardly surprising. This is one of the areas that has shown the least progress; even in the context of the most ambitious Commission legislative tax proposal (the CCCTB proposal) most of the proposed administrative functions depend on Member State tax administrations and cooperation between them. The European Commission merely has an ad hoc role.

\section{A The Fragmented Landscape}

Notwithstanding the lack of a central EU tax administration, there has long existed EU secondary legislation which provides for Member State cooperation in the form of exchange of information and assistance in the collection of taxes. In the absence of a central tax authority to oversee compliance with this legislation, the correct enforcement of the rules is left to the CJEU and the European Commission to police (through infringement actions). ${ }^{171}$ Taxpayers

${ }^{171}$ See TFEU (n 2) art 267. 
do not tend to complain about lax enforcement of such rules, unless it favours a competitor.

The pertinent rules in this area are encompassed in two directives which deal with the recovery of taxes ${ }^{172}$ and with exchange of information. ${ }^{173}$ As the titles of these instruments suggest, the Directives allow tax authorities from one Member State to seek assistance from another Member State. These directives are not exclusively relevant to companies, as they have a wide scope of application. In fact, initially these directives were primarily used to deal with emigrating individuals leaving outstanding tax bills, but nowadays they are increasingly relevant to companies. ${ }^{174}$

Under the current version of the Mutual Assistance Directive for the Recovery of Taxes, a Member State (through its competent authority) may request assistance from another Member State for the recovery ${ }^{175}$ of all taxes and duties levied by the first Member State and all its territorial or administrative subdivisions. ${ }^{176} \mathrm{~A}$ Member State may also request any information which is foreseeably relevant to the applicant authority in the recovery of its claims. ${ }^{177}$ Under limited circumstances, there can be an exchange of information without any prior request. ${ }^{178}$ The Directive also allows precautionary measures to be imposed by the other Member State, ${ }^{179}$ as well as providing for assistance in the notification of certain documents relating to claims. ${ }^{180}$

Under the Mutual Assistance Directive for the Recovery of Taxes, assistance is primarily based on a prior request by one Member State to another. If the relevant Member States agree, officials of one Member State may be present

\footnotetext{
${ }^{172}$ Mutual Assistance for the Recovery of Claims Directive (n 25).

${ }^{173}$ DAC (n 25).

174 See Christiana HJI Panayi, 'Exit Taxation as an Obstacle to Corporate Emigration from the Spectre of EU Tax Law' (2011) 13 Cambridge Yearbook of European Legal Studies 245, 27980 .

${ }^{175}$ Mutual Assistance for the Recovery of Claims Directive (n 25) art 10.

${ }^{176}$ Ibid art 1 . This includes a wide range of taxes, penalties, fees, interest and costs relating to claims. There is no recovery for compulsory social security contributions, for duties of a contractual nature such as consideration for public utilities, or criminal penalties imposed on the basis of public prosecution.

177 Ibid art 5.

${ }^{178}$ Ibid art 6 which stipulates that ' $[w]$ here a refund of taxes or duties, other than value-added tax, relates to a person established or resident in another Member State, the Member State from which the refund is to be made may inform the Member State of establishment or residence of the upcoming refund'.

${ }^{179}$ Ibid art 16.

${ }^{180}$ Ibid art 8.
} 
and participate in administrative enquiries, and court proceedings in the other Member State. ${ }^{181}$ This provision has not often been used but it is being explored by the Joint Transfer Pricing Forum ('JTPF') as far as joint audits are concerned. ${ }^{182}$ Broadly, however, the procedure in this Directive is very much governed by Member States and there is no EU institutional interference.

There is a similar procedure for cooperation under the Mutual Assistance Directive on Exchange of Information which in 2011 was renamed the Directive on Administrative Cooperation ('DAC'). ${ }^{183}$ The 2011 version of the Directive introduced an important provision for automatic exchange of information. Heavily influenced by the US Foreign Account Tax Compliance Act ('FATCA') legislation ${ }^{184}$ and the success of the now obsolete EU Savings Directive, ${ }^{185}$ it was stipulated that, from 1 January 2015, there would be automatic exchange of information for five types of income, namely: income from employment, director's fees, life insurance products not covered by other directives, pensions, and ownership of and income from immovable property. ${ }^{186}$ Whilst at the time this and other provisions ${ }^{187}$ of the new $D A C$ were hailed as

\footnotetext{
${ }^{181}$ Ibid art 7.

${ }^{182}$ See European Commission, EU Joint Transfer Pricing Forum: Discussion Paper on Joint Audits for Transfer Pricing in the EU (October 2015) <https://ec.europa.eu/taxation _customs/sites/taxation/files/docs/body/jtpf0142015jointaudits.pdf>. See also European Commission, EU Joint Transfer Pricing Forum: Presentation: Joint Audit Pilot Project Germany/the Netherlands (18 February 2016) <https://ec.europa.eu/taxation_customs/ sites/taxation/files/resources/documents/taxation/company_tax/transfer_pricing/forum/jtpf/20 16/20160218_jointauditpilot.pdf $>$. In the context of VAT, see compromise text of the proposal Council Regulation (EU) 2018/1541 of 2 October 2018 Amending Regulations (EU) No 904/2010 and (EU) 2017/2454 as regards Measures to Strengthen Administrative Cooperation in the Field of Value Added Tax [2018] OJ L 259/1. See generally IJJ Burgers and D Criclivaia, 'Joint Tax Audits: Which Countries May Benefit Most?' (2016) 8(3) World Tax Journal 306 and N Čičin-Šain, T Ehrke-Rabel and J Englisch, 'Joint Audits: Applicable Law and Taxpayer Rights' (2018) 10 World Tax Journal 77.

${ }^{183} D A C$ (n 25).

${ }^{184}$ FATCA was enacted as Title V of the Hiring Incentives to Restore Employment Act, Pub L No 111-147, §§ 501-62, 124 Stat 71. For information on the Act, see the IRS website: <https://www.irs.gov/businesses/corporations/foreign-account-tax-compliance-act-fatca>.

${ }^{185}$ Council Directive 2003/48/EC of 3 June 2003 on Taxation of Savings Income in the Form of Interest Payments [2003] OJ L 157/38. See also Council Directive (EU) 2015/2060 of 10 November 2015 Repealing Directive 2003/48/EC on Taxation of Savings Income in the Form of Interest Payments [2015] OJ L 301/1.

${ }^{186}$ See $D A C$ (n 25) art 8.

${ }^{187} \mathrm{See}$, for example, the requirement for the transmission of third country information received by one Member State to another when this is useful under $D A C$ art 16(3), or the requirement for any wider cooperation provided by a Member State to a third country to be extended to other Member States (the most-favoured-national clause) under $D A C$ art 19 etc.
} 
ground-breaking, by the time they became effective more amendments had begun to be introduced for more extensive automatic exchange of information.

The first major amendment was agreed in $2014,{ }^{188}$ in the midst of the international tax community's frantic engagement in the OECD/G20's BEPS project. This amendment introduced provisions for the automatic exchange of financial account information, similar to the OECD's Common Reporting Standard. ${ }^{189}$

The second amendment was agreed the following year following the revelations of the so-called 'Luxembourg Leaks' ${ }^{190}$ and the launch of several European Commission state aid investigations into transfer pricing rulings given by Member States to multinationals. ${ }^{191}$ The 2015 amendment introduced a very bold provision for automatic exchange of information on tax rulings and advance pricing agreements, ${ }^{192}$ under certain conditions. ${ }^{193}$ Whilst this amendment may have been inspired by the recommendations of the OECD/G20 under Action 5 of the BEPS Project ${ }^{194}$ and the subsequent elevation of these recommendations to the status of a minimum standard, ${ }^{195}$ the EU amendment went much further than this minimum standard by providing for the automatic rather than the spontaneous exchange of this information.

188 Council Directive 2014/107/EU of 9 December 2014 Amending Directive 2011/16/EU as Regards Mandatory Automatic Exchange of Information in the Field of Taxation [2014] OJ L 359/1 ('Directive 2014/107/EU').

${ }^{189}$ See OECD, Standard for Automatic Exchange of Financial Account Information Report (OECD Publishing, 2014) <http://www.keepeek.com/Digital-Asset-Management/oecd/ taxation/standard-for-automatic-exchange-of-financial-account-information-for-tax-

matters_9789264216525-en\#page1>.

190 On the Luxembourg Leaks, see 'An ICU Investigation. Luxembourg Leak: Global Companies' Secrets Exposed', International Consortium of Investigative Journalists (Web Page) <https://www.icij.org/project/luxembourg-leaks>.

${ }^{191}$ See HJI Panayi, Advanced Issues (n 21) ch 7.

192 Council Directive (EU) 2015/2376 of 8 December 2015 Amending Directive 2011/16/EU as Regards Mandatory Automatic Exchange of Information in the Field of Taxation [2015] OJ L 332/1 ('Directive 2015/2376/EU') <https://eur-lex.europa.eu/legal-content/EN/TXT/? uri=CELEX:32015L2376>.

${ }^{193}$ See HJI Panayi, 'The Europeanisation of Good Tax Governance' (n 102) pt III.C.IV and HJI Panayi, 'European Tax Law' (n 4) ch 18[17].

${ }^{194}$ Action 5 aimed to develop rules to counter harmful tax practices more effectively, taking into account transparency and substance. There were two important components of the $\mathrm{OECD} / \mathrm{G} 20$ 's proposals; firstly, the methodology to define the substantial activity requirement in the context of intangible property (the nexus approach) and, secondly, the proposed framework for compulsory spontaneous exchange of tax rulings.

${ }^{195}$ For an overview of the minimum standards, see above $\mathrm{n} 38$. 
It should be emphasised that none of the BEPS minimum standards are legally enforceable, not even by OECD member countries. Whilst there is political pressure to adopt these standards and/or amend domestic legislation accordingly, no sanctions are imposed if no such action is taken. Nevertheless, on the pretext of complying with the OECD/G20's BEPS recommendations and especially the proposals for country-by-country reporting under Action 13, ${ }^{196}$ in 2016 a third amendment to the DAC was agreed between Member States in Council which introduced the automatic exchange of country-by-country reports. ${ }^{197}$ Although, for Member States, this expedited the adoption of another BEPS minimum standard, again the amendment went further than the recommendations under Action 13. The EU legislation facilitated and enhanced the process of country-by-country reporting by removing the need to exchange such information through the more burdensome and lengthy (mostly bilateral) tax treaty mechanisms. In fact, there have even been calls for the information exchanges to be made public, though this Commission proposal ${ }^{198}$ has not (yet) been approved.

The most recent amendment, agreed in 2018, introduced the automatic exchange of reportable cross-border tax planning arrangements in order to disclose potentially aggressive arrangements. ${ }^{199}$ Again, this was heavily

${ }^{196}$ Under Action 13 of the Action Plan, the OECD was to: 'Develop rules regarding transfer pricing documentation to enhance transparency for tax administration, taking into account the compliance costs for business. The rules to be developed [would] include a requirement that MNEs provide all relevant governments with needed information on their global allocation of the income, economic activity and taxes paid among countries according to a common template.' See BEPS Action Plan (n 38).

${ }^{197}$ Council Directive (EU) 2016/881 of 25 May 2016 amending Directive 2011/16/EU as regards Mandatory Automatic Exchange of Information in the Field of Taxation [2016] OJ L 146/8 ('Directive 2016/881/EU').

198 This initiative takes the form of a proposal to amend the Accounting Directive requiring disclosure of financial accounts (2013/34/EU). As such, it only requires qualified majority and not unanimity. See Proposal for a Directive Amending Directive 2013/34/EU as Regards Disclosure of Income Tax Information by Certain Undertakings and Branches, COM(2016)198 <http://www.astrid-online.it/static/upload/fcda/fcda2c1aad7cb876d19f562507d6847a.pdf〉.

Under this proposal, MNEs (EU/non-EU) with a consolidated turnover of $€ 750$ million would be required to publish annually a report disclosing the profit and the tax accrued and paid in each Member State on a country-by-country basis for EU Member States, and in the aggregate for all non-EU countries. The information, which is less detailed than under the currently approved country-by-country reporting rules, would be made available in a stand-alone report on the company's website and be accessible to the public for at least 5 years. Companies would also have to file the report with a business register in the EU. See analysis in HJI Panayi, 'The Europeanisation of Good Tax Governance' (n 102) pt IV(A).

199 Council Directive (EU) 2018/822 of 25 May 2018 Amending Directive 2011/16/EU as Regards Mandatory Automatic Exchange of Information in the Field of Taxation in Relation to Reportable Cross-Border Arrangements [2018] OJ L 139/1 ('Directive 2018/822/EU'). Also see recently enacted Commission Implementing Regulation (EU) 2019/532 of 28 March 2019 
influenced by Action 12 of the OECD/G20's BEPS project, which, however, was not one of the minimum standards.

These recent amendments have significantly enhanced and simplified cooperation between Member States by making the automatic exchange of information more mainstream. To an extent, the 'automation' of information exchanges takes away the need for a prior request from one Member State to another, with all its associated delays and the potential legal obstacles that could arise. Of course, requests could still be made in the traditional way for further information not included in what has been automatically exchanged. However, for important categories of information, the procedure for exchange has largely been taken outside the scope of the administrative powers of Member States.

Whilst it cannot be said that the oversight of this procedure and the corollary competence has now been shifted to a Union institution, nevertheless one cannot but acknowledge the increasingly important role of the European Commission in this area. Notably, under the amendments mentioned above, automatically exchanged information on tax rulings and advanced pricing agreements and automatically exchanged information on reportable crossborder arrangements will be stored in a central directory which is to be developed by the European Commission. ${ }^{200}$ Although there is not much information as to how these central directories will be run, what safeguards and

\footnotetext{
Amending Implementing Regulation (EU) 2015/2378 as regards the Standard Forms, Including Linguistic Arrangements, for the Mandatory Automatic Exchange of Information on Reportable Cross-Border Arrangements [2019] OJ L 88/25. For commentary, see Franklin Cachia, 'Tax Transparency for Intermediaries: The Mandatory Disclosure Rules and Its EU Impact' (2018) 27(4) EC Tax Review 206-17; Roman Seer and Sascha Kargitta, 'Exchange of Information and Cooperation in Direct Taxation' in Christiana HJI Panayi et al (eds), Research Handbook in European Union Taxation Law (Elgar Publishing, forthcoming) ch 22 ('Research Handbook'). ${ }^{200}$ Under the provisions of the Directive 2015/2376/EU (n 192), the central directory will be 'accessible to all Member States and the Commission, to which Member States would upload and store information, instead of exchanging that information by secured email': Preamble [19]. The practical arrangements necessary for the establishment of such a directory are to be adopted by the Commission in accordance with the procedure referred to in $D A C$ (n 25) art 26(2). Similarly, under the provisions of the Directive introducing automatic exchange of information for reportable cross-border arrangements (Directive 2018/822/EU (n 199)), the European Commission must develop and provide with technical and logistical support a secure Member State central directory. Also, implementing powers are conferred on the European Commission to adopt the necessary practical arrangements for upgrading the central directory. See $D A C$ (n 25) Preamble, para 16. No central directory seems to be foreseen for the automatic exchange of country-by-country information. Such information will be exchanged electronically through the Common Communication Network (CCN). However, under the newly added DAC art 21 para 6 (following amendment by Directive 2016/881/EU (n 197), ' [t] he Commission shall, by means of implementing acts, adopt the necessary practical arrangements for the upgrading of the $\mathrm{CCN}$ network'.
} 
Chinese walls will be developed to avoid conflict of interests and how taxpayers' rights will be protected, this arrangement may empower the European Commission to have a more strategic involvement in supra-national cooperation.

The increased availability of automatic exchange of information has also fasttracked other forms of supra-national cooperation. Indeed, this has been the case with anti-money laundering rules. Through another amendment to the DAC,${ }^{201}$ tax authorities now have access to beneficial ownership information collected under anti-money laundering legislation (namely, the fourth AntiMoney Laundering Directive). ${ }^{202}$ This amendment follows an earlier proposal $^{203}$ to revise the fourth Anti-Money Laundering Directive to include a specific reference to tax crimes, as well as to require Member States to store beneficial ownership information in central registers which would be accessible to the public. Whilst the proposal for all Member States to create central registers of beneficial ownership information for companies, other legal entities, and trusts was approved, it was left to the discretion of Member States to decide whether to make their beneficial ownership registers public.

Through further amendments ${ }^{204}$ to the existing anti-money laundering legislation, there are now extended provisions regarding the implementation and design of ultimate beneficial ownership registers within the EU. Very importantly, registers of beneficial owners of companies operating within the EU must now be made publicly accessible and national registers must be better interconnected, to facilitate cooperation between Member States. The revised Directive provides for extended responsibility and reporting obligations and for facilitated cooperation between national financial intelligence units and bank supervisors on the exchange of information. As for third country transactions which have been identified by the European Commission as presenting an

201 Council Directive (EU) 2016/2258 of 6 December 2016 amending Directive 2011/16/EU as Regards Access to Anti-Money-Laundering Information by Tax Authorities [2016] OJ L 342/1.

202 Directive (EU) 2015/849 of the European Parliament and of the Council of 20 May 2015 on the Prevention of the Use of the Financial System for the Purposes of Money Laundering or Terrorist Financing, Amending Regulation (EU) No 648/2012 of the European Parliament and of the Council, and Repealing Directive 2005/60/EC of the European Parliament and of the Council and Commission Directive 2006/70/EC [2015] OJ L 141/73.

${ }^{203}$ Council of the European Union, Proposal for a Directive of the European Parliament and of the Council on the Prevention of the Use of the Financial System for the Purpose of Money Laundering and Terrorist Financing (12 January 2015) <http://data.consilium. europa.eu/doc/document/ST-5116-2015-ADD-2/en/pdf>.

${ }^{204}$ See Directive (EU) 2018/843 of the European Parliament and of the Council of 30 May 2018 Amending Directive (EU) 2015/849 on the Prevention of the Use of the Financial System for the Purposes of Money Laundering or Terrorist Financing, and amending Directives 2009/138/EC and 2013/36/EU [2018] OJ L 156, 43-74. 
increased risk of money laundering, the amended Directive provides tougher criteria regarding the obligation to report suspicious transactions and heavy sanctions against violations.

Apart from the above forms of administrative cooperation, there is now the Tax Dispute Resolution Directive which aims to facilitate the resolution of disputes between Member States. ${ }^{205}$ The new Directive applies, inter alia, to disputes arising from the interpretation and application of tax treaties leading to double taxation. The Directive broadens the scope of the EU rules on dispute resolution, which hitherto were limited to the Arbitration Convention and its focus on transfer pricing disputes.

More specifically, as set out in article 1, the Tax Dispute Resolution Directive lays down:

rules on a mechanism to resolve disputes between Member States when those disputes arise from the interpretation and application of agreements and conventions that provide for the elimination of double taxation of income and, where applicable, capital.

A combined reading of the provisions of this Directive suggests that double taxation may not even need to have occurred for the Directive to be applicable. Although the Tax Dispute Resolution Directive stipulates that a Member State may, on a case by case basis, deny access to the dispute resolution procedure where the dispute does not involve double taxation, ${ }^{206}$ the starting point is that even disputes not involving double taxation are within the scope of the Directive. This is also buttressed by the preamble to this Directive. ${ }^{207}$ Therefore, the new Directive not only covers disputes on double taxation but can also cover disputes arising from the wrongful application of any of the procedural provisions (for example, provisions on exchange of information, or assistance in the collection of taxes and so forth).

\footnotetext{
205 Member States had until 30 June 2019 to transpose the Directive into national laws and regulations. The Directive applies to complaints submitted after that date on questions relating to the tax year starting on or after 1 January 2018. Member States may, however, agree to apply the Directive to complaints related to earlier tax years. See Tax Dispute Resolution Directive (n 27).

${ }^{206}$ Tax Dispute Resolution Directive (n 27) art 17(6).

${ }^{207}$ Ibid Preamble [6] which sets out that the resolution of disputes envisaged under the Tax Dispute Resolution Directive, 'should apply to different interpretation and application of bilateral tax treaties and of the Union Arbitration Convention - in particular to different interpretation and application leading to double taxation'.
} 
Under the new Tax Dispute Resolution Directive, any person who is a tax resident of a Member State and whose taxation is directly affected by a matter giving rise to a dispute, may simultaneously submit a complaint to each of the concerned EU competent authorities. ${ }^{208}$ Within a period of six months from having received all the necessary documents, any of the concerned competent authorities may decide to resolve the dispute on a unilateral basis. If that does not happen, then the relevant competent authorities of the Member States involved must endeavour to solve the dispute by means of a mutual agreement procedure within a period of two years. ${ }^{209}$ Any agreement reached under the mutual agreement procedure is binding on the competent authorities and enforceable by the taxpayer. ${ }^{210}$

If no agreement is reached, then, upon a request by the taxpayer to the competent authorities of the Member States concerned, an Advisory Commission is set up. ${ }^{211}$ The new Directive provides for mandatory resolution of double taxation disputes. Alternatively, Member States are able to request an Alternative Dispute Resolution Commission to be set up instead of the Advisory Commission, which will also deal with the dispute in a binding manner. ${ }^{212}$ Taxpayers have several appeal possibilities to ensure that the competent authorities will apply the provisions of the Tax Dispute Resolution Directive.

The new Directive sets out when access to national courts should be granted for the purpose of clarifying whether there is an obligation to eliminate double taxation. If there is such an obligation, the Tax Dispute Resolution Directive provides the national court with the power to take action. ${ }^{213}$ Furthermore, the new Tax Dispute Resolution Directive allows Member States to choose the methods for solving their double taxation disputes provided that double taxation is eliminated within the timeframes laid down in the Directive. In addition, the Tax Dispute Resolution Directive allows the European Commission to assist Member States in the proceedings and increases transparency by requiring at least the abstracts of the decisions to be published. The European Commission is, once again, tasked with the development of a central repository which will archive the opinions of the Advisory Commissions and of the Alternative

\footnotetext{
208 This right must be exercised within three years from the receipt of the first notification of the action resulting in, or that will result in, the dispute: ibid art 3.

${ }^{209}$ Ibid art 4(1).

210 Ibid art 4(2).

211 Ibid art 6 . The relevant competent authorities must also inform the taxpayer of the reasons that no agreement was reached: art 4(3).

212 Ibid art 10.

213 Ibid art 16.
} 
Dispute Resolution Commissions (either the final decisions or the abstracts) and make them available online. ${ }^{214}$

The processes discussed above are still largely supra-national and dependent on cooperation between Member States, albeit embedded in the normative and much more easily enforceable context of EU law. Nevertheless, one can easily detect the European Commission's enhanced involvement which could lead to creeping competences. The central directories which are to be developed by the European Commission following the amendments to the $D A C$, and the central repository of opinions under the new Tax Dispute Resolution Directive are a starting point. Such central directories/repositories could eventually lead to the allocation of more centralised administrative functions to the European Commission, not just in the area of information exchange but in other aspects of tax administration.

Acquiring a more important role in the EU's tax administration may not be such a big leap for the European Commission. As shown in Part IV, the European Commission already has important centralised functions in the context of the state aid regime, including fiscal state aid. More specifically, the European Commission is the only EU institution that can launch state aid investigations and deliver the first instance decisions which, if not appealed in the European courts, are final and binding on Member States. The European Commission also develops guidelines and other types of soft law in this area. ${ }^{215}$ The recent Commission investigations into Member States' transfer pricing tax rulings show just how much power the European Commission wields in this area. Of course, the ultimate arbiter in this and many other areas is the CJEU. Nevertheless, as the investigations are launched and pursued by the European Commission in a largely discretionary manner, ${ }^{216}$ the European Commission arguably has a significant role in determining what aid may and may not to be scrutinised at EU level.

Other older and more recent initiatives also seem to buttress the growing importance of the European Commission as an ad hoc EU tax administration. In the early 2000s, the European Commission negotiated on behalf of the Union

\footnotetext{
214 Ibid art 19.

${ }^{215}$ See generally, 'State Aid Control' European Commission (Web Page) <http://ec.europa.eu/ competition/state_aid/overview/index_en.html>.

${ }^{216}$ The European Commission has substantial discretion in the overall process as it is entitled to set priorities in relation to state aid complaints and give differing degrees of priority. The procedure is essentially a bilateral one between the European Commission and the Member State that has conferred the aid. There are no material procedural rights conferred to interested parties - whether the beneficiary of the aid or the competitor.
} 
the EU savings taxation agreements with some non-EU European countries, namely: Andorra, Liechtenstein, Monaco, San Marino and Switzerland. ${ }^{217}$ These agreements were considered to be necessary to enable the Union to exercise its internal competence, though it was emphasised that the Union did not have exclusive competence ${ }^{218}$ to conclude such agreements. ${ }^{219}$ Similar bilateral savings taxation agreements were also signed with the dependent territories of the Netherlands and the UK (Anguilla, Aruba, the British Virgin Islands, the Cayman Islands, Guernsey, the Isle of Man, Jersey, Montserrat, the Netherlands Antilles and the Turks and Caicos Islands), and other European countries (Andorra, Liechtenstein, Monaco, San Marino and Switzerland). More recently, the European Commission was entrusted with the revision of these agreements in order to align the regulatory framework of these European countries with that introduced under the 2014 amendment $^{220}$ to the $D A C,{ }^{221}$ discussed above.

Perhaps the most obvious example of the European Commission acting as a central tax authority is in the context of developing the EU's external fiscal policy and more specifically in the creation of the EU list of non-cooperative tax jurisdictions. For such initiatives, it tends to be assisted by other informal (and unelected) bodies, which also seem to wield substantial power. This is discussed next.

\footnotetext{
${ }^{217}$ See generally Christiana HJI Panayi, 'The Relationship between EU and International Tax Law' in HJI Panayi, Research Handbook (n 199).

218 See European Commission, Proposal for a Council Decision on the Conclusion of the Agreement between the European Community and the Swiss Confederation Providing for Measures Equivalent to Those Laid Down in Council Directive 2003/48/EC of 3 June 2003 on Taxation of Savings Income in the Form of Interest Payments and the Accompanying Memorandum of Understanding, COM (2004) 75 final, 3.

${ }^{219}$ Interestingly, about 20 years earlier, in 1983, the European Commission had unsuccessfully claimed competence to negotiate a multilateral agreement on exchange of information with the Council of Europe, and failed to obtain a mandate due to the concerns of the Member States. See Recommendation for a Council Decision Authorizing the Commission to Negotiate a Multilateral Convention on Administrative Assistance in Tax Matters within the Council of Europe, COM (83) 685 final, 22 November 1983. This recommendation was subsequently withdrawn on 13 April 1988.

${ }^{220}$ Directive 2014/107/EU (n 188).

${ }^{221}$ For the current status of these updated agreements, see 'International Developments', European Commission (Web Page) <https://ec.europa.eu/taxation_customs/individuals/ personal-taxation/taxation-savings-income/international-developments_en>.
} 


\section{B Is There Centralisation of Soft Law Fiscal Powers?}

Whilst there is no official central tax authority for EU tax matters, some unifying and increasingly empowering soft law is generated from the European Commission or expert groups such as the Joint Transfer Pricing Forum, the VAT Group and the Platform for Tax Good Governance. These groups comprise experts from Member State tax authorities, the business sector and NGOs appointed by the European Commission to assist and advise it in the underlying areas. ${ }^{222}$

As discussed in Part IV, the Joint Transfer Pricing Forum has produced extensive guidance on transfer pricing issues. ${ }^{223}$ Some of this guidance even influenced the recommendations produced under the OECD/G20's BEPS project. For example, on the basis of the work of the Joint Transfer Pricing Forum, in 2011, the European Commission published a Communication setting out guidelines on transfer pricing issues related to low-value-adding intra-group services and non-EU triangular services. ${ }^{224}$ The influence of this Communication on the OECD/G20's recommendations on low value-adding intra-group services ${ }^{225}$ is obvious. The Joint Transfer Pricing Forum's work has also been pioneering as far as country-by-country reporting is concerned. In 2006, again as a result of the work of the Forum, a Code of Conduct on the transfer pricing documentation for associated enterprises in the EU was

\footnotetext{
${ }^{222}$ The Tax Policy Group and the Recovery Committee are other advisory groups listed on the Commission's website but there is not much information as to the composition and functioning of this group. The Expert Group on Taxation of Digital Economy is also still listed, even though it does not appear to have been active since 2014. See 'Further Reading', European Commission (Web Page) <https://ec.europa.eu/taxation_customs/fight-against-tax-fraud-tax-evasion/ further-reading_en>.

${ }^{223}$ See above $\mathrm{n} 142$.

${ }^{224}$ European Commission, Communication Setting Out 1. Guidelines on Technical Issues Related to Transfer Pricing Taxation, including Low-Value-Adding Intra-Group Services and 2. Potential Approaches to Non-EU Triangular Services (COM(2011)16 final) <https://eurlex.europa.eu/legal-content/EN/TXT/HTML/?uri=CELEX:52011DC0016\&from=EN>. See also Council of the European Union, 'Council Conclusions on the Communication from the Commission on the Work of the EU Joint Transfer Pricing Forum in the Period April 2009 to June 2010 and Related Proposals: 1. Guidelines on Low Value Adding Intra-Group Services and 2. Potential Approaches to Non-EU Triangular Cases' (Press Release, 17 May 2011) $<$ https://ec.europa.eu/taxation_customs/sites/taxation/files/docs/body/council_conclusions_jtp f.pdf $>$.

225 OECD, Public Discussion Draft - BEPS Action 10: Proposed Modifications to Chapter VII of the Transfer Pricing Guidelines relating to Low Value-Adding Intra-Group Services 3 November 2014-14 January 2015 (3 November 2014) <http://www.oecd.org/ctp/transferpricing/discussion-draft-action-10-low-value-adding-intra-group-services.pdf $>$.
} 
published. ${ }^{226}$ The Code of Conduct provided a template for standardised and partially centralised transfer pricing documentation for associated enterprises in the EU. It was addressed to Member States but was also intended to encourage MNEs to apply the standardised approach. Member States were urged to accept the standardised documentation and consider it as a basic set of information for the assessment of an MNE's transfer prices. The use of standardised documentation was optional but it provided an incentive to minimise the administrative costs of complying with several national transfer pricing documentation requirements. Country-by-country reporting was a major theme of the BEPS project and eventually became one of the minimum standards.

Many recent tax initiatives or legislative proposals either originated or were discussed in the context of the Platform for Tax Good Governance. Through several discussion papers, the Platform has considered issues such as whether to adopt a general anti-abuse rule in the context of the Parent-Subsidiary Directive, what criteria should be applied by Member States to establish lists of non-cooperative jurisdictions, how to improve dispute resolution, how to implement mandatory disclosure for some aggressive tax arrangements, the external strategy for effective taxation, the protection of whistle-blowers, the taxation of digital economy and much more. ${ }^{227}$

The EU Code of Conduct Group is another informal body created in $1998^{228}$ to help implement the Code of Conduct for business taxation ${ }^{229}$ in order to tackle harmful tax competition at the time. The Code of Conduct Group is an unelected informal body, composed of high-level officials of Member States but also reliant on the general secretariat of the Council of the EU. It does not take any formal decisions but its recommendations have great political weight. The work of the Group is confidential and focuses on legislator behaviour rather

\footnotetext{
${ }^{226}$ See Resolution of the Council and of the Representatives of the Governments of the Member States, Meeting within the Council, of 27 June 2006 on a Code of Conduct on Transfer Pricing Documentation for Associated Enterprises in the European Union, [2006] OJ C 176/1 <http://eur-lex.europa.eu/legal-content/EN/TXT/?uri=CELEX:42006X0728\%2801\%29>.

227 'Platform for Tax Good Governance' European Commission (Web Page) <https://ec. europa.eu/taxation_customs/business/company-tax/tax-good-governance/platform-tax-goodgovernance_en>.

${ }^{228}$ Council of the European Union, Council Conclusions of 9 March 1998 Concerning the Establishment of the Code of Conduct Group for Business Taxation [1998] OJ C 99/1.

${ }^{229}$ EU Code of Conduct (1997): Conclusions of the ECOFIN Council Meeting on 1 December 1997 Concerning Taxation Policy [1997] OJ C 2/1. This Code of Conduct had been adopted by the Council the previous year, in the context of the EU's fight against harmful tax competition. See European Commission, Communication from the Commission to the Council - Towards Tax Co-ordination in the European Union, A Package to Tackle Harmful Tax Competition $\operatorname{COM}(97) 495$ final, 1 October1997.
} 
than taxpayer behaviour. ${ }^{230}$ When the Code of Conduct Group was first established, it was asked to assess whether or not certain Member State tax rules could be considered harmful tax practices - an exercise similar to that undertaken by the OECD in the context of its Harmful Tax Competition project in $1998 .^{231}$ Its work in this area has been very successful ${ }^{232}$ and the Code of Conduct Group continues to monitor potentially harmful tax measures. ${ }^{233}$

It is notable that the Code of Conduct on Business Taxation contains provisions which go beyond the initial concern of harmful tax competition. For example, paragraphs $\mathrm{K}$ and $\mathrm{L}$ of the Code promote action to curb tax avoidance and evasion. Paragraph $\mathrm{M}$ of the Code also focuses on the geographical extension of the rules on harmful tax competition and the policy towards third countries. When the Code was first introduced, it was considered essential that it should apply to as broad a geographical area as possible. On this basis, Member States with dependent or associated territories were urged to ensure that the principles of the Code applied to those territories.

These paragraphs have enabled the Code of Conduct Group to expand its work into several areas dealing with administrative practices (for example, crossborder rulings) and anti-abuse mechanisms (for example, hybrid instruments, hybrid entities and hybrid permanent establishments, hybrid permanent establishments and third countries and so forth. ${ }^{234}$ Third-country issues have

\footnotetext{
${ }^{230}$ Martijn Nouwen, 'The Gathering Momentum of International and Supranational Action against Aggressive Tax Planning and Harmful Tax Competition: The State of Play of Recent Work of the OECD and European Union' (2013) 53(10) European Taxation 9. Also see Vinod Kalloe, 'EU Code of Conduct: From Reviewing Individual Tax Regimes to Developing Horizontal Policy: Cracking the Code in the BEPS Era' (2016) 56(5) European Taxation 183.

${ }^{231}$ OECD, Harmful Tax Competition: An Emerging Global Issue (OECD Publications, 1998).

${ }^{232}$ The first report of the Code of Conduct Group (also known as the Primarolo Report) listed 66 preferential tax measures that had been found to be harmful. The Primarolo Report also listed six categories of harmful tax measures relating to insurance practices, financial services, transfer pricing, holding company regimes, exempt and offshore entities. Interim draft reports were published in 1998. Since then, and after the publication of various guidelines, the Member States and the associated/dependent territories concerned have largely dismantled these measures.

${ }^{233}$ See the various reports of the Code of Conduct Group to Council since 1999, available at: <https://www.consilium.europa.eu/register/en/content/out?DOC_TITLE=business\%20taxatio n\&ORDERBY=DOC_DATE\%20DESC $\& D O C \_L A N C D=E N \& R E S U L T S E T=1 \& D O C \_S U B$ TYPE $=\% 22$ REPORT $\% 22 \& \mathrm{i}=\mathrm{COCGRTTC} \& \mathrm{ROWSPP}=25 \& \mathrm{ty} \mathrm{p}=\mathrm{SET} \& \mathrm{NRROWS}=500 \& \mathrm{TA}$ RGET_YEAR=2019>.

${ }^{234}$ See HJI Panayi, Advanced Issues (n 21) ch 5, pt 5.6; Kalloe (n 230) 186-7, and references therein. For the more recent guidance on hybrid PEs and third countries, see Code of Conduct Group (Business Taxation), Code of Conduct (Business Taxation) - Report to the Council (Report, doc 9912/16, Council of the European Union, 13 June 2016) <http://data. consilium.europa.eu/doc/document/ST-9912-2016-INIT/en/pdf>. See also Elizabeth Gil
} 
also been addressed in the context of the dialogue between the EU and non-EU countries - especially Liechtenstein and Switzerland - on the application of the principles and the criteria contained in the Code of Conduct on Business Taxation. ${ }^{235}$

Recently, some ground-breaking synergies appear to be resulting from the unofficial cooperation/coordination between the European Commission, the Commission-appointed expert groups and the Code of Conduct Group. The best example of these is the EU list of non-cooperative jurisdictions, which is proving to be very influential in the development of a common fiscal policy externally. The EU list was spearheaded by the European Commission in the context of its work on a common external fiscal strategy, assisted by the Platform for Tax Good Governance. The role of the Code of Conduct Group in assessing and monitoring countries for the purposes of this list was also decisive. The overall implementation of this project, which is ongoing, relies heavily on the European Commission and the Code of Conduct Group.

The first steps towards developing a uniform approach to non-cooperative (nonEU) tax jurisdictions were taken with the European Commission's Action Plan for a Fair and Efficient Corporate Tax System in June 2015. ${ }^{236}$ In the context of this Action Plan, the European Commission published a first pan-EU online map of third-country non-cooperative tax jurisdictions. This was a map of nonEU tax jurisdictions which Member States had considered uncooperative under their own systems. In other words, initially, the European Commission used Member States' benchmarks for noncompliance and not its own. There were about 30 non-EU tax jurisdictions in the first version of the map. ${ }^{237}$ The map was to be updated periodically and used to develop a common EU strategy to deal with such jurisdictions, including via coordinated countermeasures.

Garcia, 'Addressing Hybrid PE Mismatches: The Guidance of the Code of Conduct Group' (2017) 57(2/3) European Taxation 94.

${ }^{235}$ For a compilation of the Guidance Notes agreed by the Code of Conduct Group (Business Taxation) since its creation in March 1998, see General Secretariat of the Council, Agreed Guidance by the Code of Conduct Group (Business Taxation): 1998-2018 (Report, doc 5814/3/18 Rev 3, Council of the European Union, 13 July 2018) <http://data. consilium.europa.eu/doc/document/ST-5814-2018-REV-3/en/pdf>.

${ }^{236}$ See $\mathrm{n} 41$.

${ }^{237}$ Obviously, the first version has been replaced by later versions. The map is no longer available online as it has been superseded by the EU list of non-cooperative tax jurisdictions. See 'Common EU List of Third Country Jurisdictions for Tax Purposes', European Commission (Web Page) <https://ec.europa.eu/taxation_customs/business/company-tax/tax-good-govern ance/tax-good-governance-world-seen-eu-countries_en>. 
Indeed, in its Communication on External Strategy, ${ }^{238}$ the European Commission devised the steps to be taken in order to develop a common strategy. As a first step, the European Commission would identify the third countries that should be prioritised for screening, according to its key indicators. The results of this so-called scoreboard approach were published by the European Commission in September 2016. ${ }^{239}$ As a second step, Member States would decide which jurisdictions should be assessed on the basis of criteria agreed between them. Again, the European Commission exerted important influence on the criteria that were eventually approved by ECOFIN in November $2016^{240}$ and used in the subsequent screening process by the Code of Conduct Group. The screening process was coordinated with the Council's High Level Working Party on Taxation, and heavily supported and guided by the European Commission. The process was completed by September 2017 and Member States were called to endorse the list of non-cooperative jurisdictions.

The third step was Member State (that is, ECOFIN) approval of the final EU list of non-cooperative jurisdictions, which effectively rubber-stamped the European Commission's work in this area. The EU list (also colloquially called the EU blacklist) was approved by ECOFIN in December 2017. Seventeen countries $^{241}$ were identified as failing to meet the agreed criteria, and 47 countries were identified as having committed to addressing deficiencies in their tax systems and to meeting the required criteria. ${ }^{242}$ The European

\footnotetext{
${ }^{238}$ External Strategy Communication (n 109) 11.

239 'First Step towards a New EU List of Third Country Jurisdictions - Scoreboard' European Commission (Web Page, September 2016) <https://ec.europa.eu/taxation_customs/sites/ taxation/files/2016-09-15_scoreboard-indicators.pdf\#page=1\&zoom=auto,-20,842>.

${ }^{240}$ General Secretariat of the Council, 'Criteria and Process Leading to the Establishment of the EU List of Non-Cooperative Jurisdictions for Tax Purposes - Council Conclusions' (Report, doc 14166/16, Council of the European Union, 8 November 2016) <http://www.consilium. europa.eu/media/24230/08-ecofin-non-coop-juris-st14166en16.pdf>. Effectively, ECOFIN adopted the Commission recommendations (see main recommendations and Annex I of the Commission Communication on External Strategy (n 109)) and set out the following criteria to be used to assess countries for the purposes of the EU listing process: tax transparency, fair taxation and BEPS implementation (of the minimum standards). See also analysis in HJI Panayi, 'The Europeanisation of Good Tax Governance' (n 102) pt IV(C).

${ }^{241}$ The 17 jurisdictions on the list were the following: American Samoa, Bahrain, Barbados, Grenada, Guam, Korea, Macao, Marshall Islands, Mongolia, Namibia, Palau, Panama, Saint Lucia, Samoa, Trinidad and Tobago, Tunisia, United Arab Emirates. Georgia has also been listed by mistake and removed the following day.

${ }^{242}$ The European Commission excluded 48 least developed countries from the pre-assessment and delayed the screening for jurisdictions of the Caribbean area (Anguilla, Antigua and Barbuda, Bahamas, British Virgin Islands, Dominica, Saint Kitts and Nevis, Turks and Caicos Islands and US Virgin Islands) due to the natural disaster that affected the region in September 2017.
} 
Commission encouraged Member States to agree on coordinated sanctions against the listed jurisdictions, such as increased monitoring and audits, the withholding of taxes, the imposition of special documentation requirements and of anti-abuse provisions.

Following this ground-breaking development, several more countries were removed from or added to the EU list. Later on, ECOFIN published a consolidated list, together with a consolidated version of the state of play. ${ }^{243}$ Soon thereafter, the European Commission published guidelines ${ }^{244}$ on the use of EU funds in order to ensure that such funds are not channelled or transited through entities that are resident in blacklisted tax jurisdictions. This was largely expected, given the warnings published in the European Commission's Q\&A fact sheet accompanying the first version of the EU list. ${ }^{245}$ Following the European Commission's guidelines, funding by International Financial Institutions such as the European Investment Bank and the various Development Financial Institutions can no longer be channelled through listed jurisdictions. ${ }^{246}$ The guidelines also provide information on how implementing partners should assess projects that involve entities in listed jurisdictions. ${ }^{247}$

\footnotetext{
${ }^{243}$ See General Secretariat of the Council, 'The EU List of Non-Cooperative Jurisdictions for Tax Purposes - State of Play of the Cooperation with the EU with respect to Commitments Taken to Implement Tax Good Governance Principles' (Report, doc 6236/1/18 Rev 1, Council of the European Union, 19 March 2018) <http://data.consilium.europa.eu/doc/document/ST6236-2018-REV-1/en/pdf>.

${ }^{244}$ See European Commission, Communication on New Requirements against Tax Avoidance in EU Legislation Governing in Particular Financing and Investment Operations, C(2018) 1756 final, Brussels, 21.3.2018 <https://ec.europa.eu/info/sites/info/files/economy-finance/c_2018_ 1756_en_0.pdf>.

${ }^{245}$ This was also released on 5 December 2017: European Commission, 'Questions and Answers on the EU List of Non-Cooperative Tax Jurisdictions' (Fact Sheet, 5 December 2017) <http://europa.eu/rapid/press-release_MEMO-17-5122_en.htm>.

${ }^{246}$ Standardised wording referring to the adoption of the EU list of non-cooperative jurisdictions has already been inserted into various EU legal acts, such as Regulation (EU) 2017/1601 of the European Parliament and of the Council of 26 September 2017 (establishing the European Fund for Sustainable Development (EFSD), the EFSD Guarantee and the EFSD Guarantee Fund) [2017] OJ L 249/1 (establishing the European Fund for Sustainable Development) and Regulation (EU) 2015/1017 of the European Parliament and of the Council of 25 June 2015 on the European Fund for Strategic Investments, the European Investment Advisory Hub and the European Investment Project Portal and amending Regulations (EU) No 1291/2013 and (EU) No 1316/2013 - The European Fund for Strategic Investments [2015] OJ L 169 (establishing the European Fund for Strategic Investments).

${ }^{247}$ Implementing Partners are entities implementing EU funds under indirect management (generally international financial institutions and development financial institutions). Implementing Partners have to perform tax avoidance checks on all relevant entities involved in a project, as well as align their internal policies with the EU's policy on non-cooperative jurisdictions for tax purposes. Although Implementing Partners are invited to review their
} 
At the time of writing, the last update of this list took place at the June 2019 ECOFIN meeting. By that time, following the Code of Conduct Group's recommendations, 10 more jurisdictions were added to the list for failing to comply with commitments by the agreed deadlines, namely: Aruba, Barbados, Belize, Bermuda, Dominica, Fiji, the Marshall Islands, Oman, the United Arab Emirates and Vanuatu. ${ }^{248}$ In May 2019, Bermuda, Aruba, and Barbados were again removed from the EU list. At the June ECOFIN meeting ${ }^{249}$ it was decided to remove Dominica from the list, which now includes the following 11 jurisdictions: American Samoa, Belize, Fiji, Guam, the Marshall Islands, Oman, Samoa, Trinidad and Tobago, the United Arab Emirates, the US Virgin Islands, and Vanuatu.

This whole process has been criticised for the lack of transparency in selecting the criteria for listing or delisting countries and the possible sanctions. It has also been criticised for the fact that EU Member States were not considered for assessment. $^{250}$ Although, in February 2018, the Code of Conduct Group published the letters seeking commitments from the non-cooperative jurisdictions, ${ }^{251}$ this was still not considered to be satisfactory. The lack of transparency during the listing/delisting process and the lack of credibility of

existing portfolio with respect to EU policy, the EU blacklist only applies to new and renewed operations.

248 See General Secretariat of the Council, 'The Revised EU List of Non-Cooperative Jurisdictions for Tax Purposes - Council Conclusions', Council of the European Union (Report, doc 7441/19, 12 March 2019) <https://www.consilium.europa.eu/media/38450 /st07441-en19-eu-list-oop.pdf>.

${ }^{249}$ See June 2019 ECOFIN note on changes to the EU list of non-cooperative jurisdictions, Council of the European Union, Report by the Code of Conduct Group (Business Taxation) suggesting amendments to the Annexes of the Council conclusions of 12 March 2019, including the de-listing of one jurisdiction (6 June 2019) <https://data.consilium.europa.eu/doc/ document/ST-9674-2019-REV-1/en/pdf>.

${ }^{250}$ Indicatively, shortly before the release of the EU list, Oxfam published its own research on tax havens, based on the Commission's screening criteria. More specifically, Oxfam applied these criteria to all the countries being screened by the Commission, as well as to all the Member States. According to the results of Oxfam's analysis, a robust application of the Commission's criteria would lead to at least 35 non-EU countries to be included in the EU list. Oxfam also found that four Member States (Ireland, Malta, Netherlands and Luxembourg) would likely fail the Commission's criteria. See Aurore Chardonnet and Johan Langerock, 'Blacklist or Whitewash? What a Real EU Blacklist of Tax Havens Should Look Like', Oxfam International (Oxfam Briefing Note, 27 November 2017) <https://www.oxfam.org/en/research/blacklist-orwhitewash-what-real-eu-blacklist-tax-havens-should-look>.

${ }^{251}$ See General Secretariat of the Council, 'The EU List of Non-Cooperative Jurisdictions for Tax Purposes. Compilation of Letters Seeking Commitment' (Report, doc 6671/18, Council of the European Union, 6 March 2018) <http://data.consilium.europa.eu/doc/document/ST-66712018-INIT/en/pdf>. 
the resulting blacklist have also been discussed in the European Parliament ${ }^{252}$ but without resulting in any changes. Although the Austrian Presidency of the EU has reportedly considered whether Member States should also be subject to the review process conducted by the Code of Conduct Group for the purposes of the blacklist, ${ }^{253}$ no concrete steps have yet been taken to that effect. ${ }^{254}$

Putting aside the problematic nature of this blacklist, what is remarkable is how the European Commission, assisted by other informal and unelected bodies, is slowly acquiring some functions of a tax administration in this area and is doing so with the tacit approval of Member States. At least insofar as the EU list of non-cooperative jurisdictions is concerned, not only did the European Commission design and subsequently hijack the whole process (with debatable competence to do so), ${ }^{255}$ but it is also involved in the development of common sanctions which could go some way towards replicating important functions of a national tax authority.

\section{The Peripatetic Nature of EU Corporate Tax LAW AND BREXIT}

This article has reviewed some aspects of the EU's tax set-up which correspond to aspects of a country's corporate tax regime. The article began by explaining the difficulties and constraints in developing a coherent and uniform body of corporate tax legislation, due to the constitutional requirement of unanimity in decision-making among Member States. The result is a patchwork of hard law and soft law, which has been created mostly on an ad hoc basis and often as a reaction to other international developments or EU milestones. What could broadly be perceived as EU corporate tax law has been scrutinised in the context of the following topics: the existence of a uniform tax base and tax rates, the

\footnotetext{
252 See European Parliament, Parliamentary Debates, Brussels, 28 February 2018 <http://www.europarl.europa.eu/sides/getDoc.do?pubRef=-//EP//TEXT+CRE+20180228 + ITEM-025+DOC+XML+V0//EN\&language $=\mathrm{EN}>$.

${ }^{253}$ See Francesco Guarascio, 'EU Weighs Screening Member States over Tax Avoidance Official', Reuters (Web Page, 10 October, 2018) <https://www.reuters.com/article/eu-taxavoidance/eu-weighs-screening-member-states-over-tax-avoidance-official-idUSL8N1 WQ4VB>.

${ }^{254}$ This was implicitly recommended in the TAXE 3 European Parliament committee report, where it was stated that some Member States functioned as corporate tax havens. See European Parliament, Report on Financial Crimes, Tax Evasion and Tax Avoidance. European Parliament Resolution of 26 March 2019 on Financial Crimes, Tax Evasion and Tax Avoidance (2018/2121(INI)) (Report, doc P8_TA-PROV(2019)0240, European Parliament. 26 March 2019) [330] <http://www.europarl.europa.eu/cmsdata/162244/P8_TA-PROV(2019)0240. pdf>.

${ }^{255}$ For criticism, see HJI Panayi, 'The Europeanisation of Good Tax Governance' (n 102).
} 
existence of anti-abuse rules and transfer pricing rules and, finally, the existence of a common tax administration.

It has been shown that, whilst there is currently neither a uniform (EU) tax base nor a uniform tax rate, several legislative proposals are in the pipeline which seek to change this situation to some extent. This article has reviewed the pending CCTB and CCCTB Directives, which aim to provide common rules for a corporate tax base and, more innovatively, for cross-border consolidation. Although the foundations of these draft Directives are older European Commission proposals which were never approved, the fact that, in the new proposals, the issues of the common tax base and cross-border consolidation are addressed separately increases the likelihood of at least one of them being unanimously approved by Member States. Furthermore, the fact that, under the new proposals, the attention has shifted from the objective of facilitating corporate groupings and simplifying tax compliance to the objective of countering tax avoidance and aggressive tax planning also increases this likelihood.

This article has also reviewed the embattled proposal for the FTT, which provides for a common tax levy (that is, a common tax rate) on certain transactions. The strong disagreements with this proposal, and the fate of the subsequently modified proposal, to be applied by a few Member States only on the basis of enhanced cooperation, are indicative of the overall dynamics and challenges faced in this area.

More recent proposals for taxing the digital economy have also been considered. These proposals have an impact both on the corporate tax base and the tax rate imposed by Member States. For example, the proposal for a 'digital permanent establishment' concept based on significant digital presence interferes with the discretion of Member States to define the boundaries of what they consider a permanent establishment for the purposes of exercising their taxing powers. It therefore represents an important erosion of their tax sovereignty. Furthermore, the digital permanent establishment concept goes beyond the definition found in the OECD Model Tax Convention ${ }^{256}$ which most Member States follow, thus potentially interfering with the traditional allocation of taxing rights that is adopted in tax treaties with third countries. The second proposal introduces a digital services tax of $3 \%$ on revenues resulting from the provision of certain digital services. ${ }^{257}$ This imposition of

\footnotetext{
${ }^{256}$ See OECD Model Tax Convention (n 10) art 5.

${ }^{257}$ European Commission, Proposal for a Council Directive on the Common System of a Digital Services Tax on Revenues Resulting from the Provision of Certain Digital Services, $\operatorname{COM}(2018) 148$ final, 21 March 2018.
} 
what seems to be a direct tax, ${ }^{258}$ however small, on certain types of activities is an undeniable encroachment on the powers of Member States to determine the scope of their tax bases and their corporate tax rates. Furthermore, the huge shift in taxation rights based on the location of the digital user in value creation, if applied unilaterally by the EU, might be difficult to enforce and would harm international cooperation. Strong concerns about this have already been voiced by the US government. ${ }^{259}$ It would also potentially harm the competitiveness of the EU and its ability to attract digital businesses (whether start-ups or established businesses).

The article has also examined one of the most paradoxical developments in this area: the adoption of uniform anti-abuse rules under the $A T A D$, in the absence of a comprehensively harmonised corporate tax system. It has been shown that these rules, combined with the ad hoc anti-abuse rules in some of the corporate tax directives and the often contradictory principles derived from the case law of the CJEU, are jeopardising legal certainty and undermining future efforts to create a more streamlined EU corporate tax system. The treatment of basic transfer pricing concepts such as the arm's length principle under soft law and hard law (that is, the case law of the CJEU on the basis of fundamental freedoms and the state aid prohibition) shows the extent to which there is uncoordinated and, arguably, 'erratic' EU interference in this area.

It has been shown in this article that the area where there has been least coordination and harmonisation is that of tax administration. It would seem that tax administration functions, such as cross-border cooperation and the exchange of information amongst Member States, are largely decentralised and governed by Member State competent authorities. The same model of governance even seems to be replicated in the proposed CCTB/CCCTB Directives. ${ }^{260}$ Only as regards the development of an external fiscal policy does there appear to be a gravitational pull towards centralising administrative

\footnotetext{
${ }^{258}$ Interestingly, an EU Council opinion concluded that the appropriate legal basis for the tax should be art 115 and not art 113 of the TFEU, on the basis of which the proposal was made: Council of the European Union, 'Opinion of the Legal Service' 2018/0073(CNS) (8 October 2018) <https://dlbjbjzgnk95t.cloudfront.net/1091000/1091097/dst\%20opinion.pdf>.

${ }^{259}$ See, for example, US Treasury Secretary Steven T Mnuchin's statement regarding digital tax proposals, released on 25 October 2018: 'I highlight again our strong concern with countries' consideration of a unilateral and unfair gross sales tax that targets our technology and internet companies. A tax should be based on income, not sales, and should not single out a specific industry for taxation under a different standard. We urge our partners to finish the OECD process with us rather than taking unilateral action in this area': US Department of the Treasury, 'Secretary Mnuchin Statement on Digital Economy Taxation Efforts' (25 October 2018) <https://home.treasury.gov/news/press-releases/sm534>.

${ }^{260}$ See Draft CCCTB Directive (n 44) ch IX.
} 
functions in the hands of the European Commission, as assisted by the Code of Conduct Group and informal bodies of experts. What is unfortunate is that any plans for reform in this area, however ambitious or modest, do not address the growing administrative powers and vague obligations of the European Commission and the lack of institutional checks and balances.

It is questionable whether this welter of conflicting principles which result from the peripatetic nature of EU corporate tax law is suitable for a Union which aspires to have one of the most competitive economies in the world. Arguably, this patchwork of rules and principles undercuts the Union's potential for growth and development. Whilst case law imposes strict proportional and substance-related thresholds for any national anti-abuse rules, secondary legislation does not seem to follow those strict thresholds. Similarly, whilst de minimis secondary legislation provides relief for double taxation of passive investment or facilitates cross-border reorganisations (under very strict conditions), at the same time more general case law either provides more generous treatment to taxpayers or draws unintelligible distinctions and makes unpredictable exceptions. ${ }^{261}$ Furthermore, whilst a growing body of legislation facilitates the cross-border exchange of information and assistance in the recovery of taxes, there is no central tax administration overseeing the effectiveness of the rules and compliance with them. Not only that, but within the EU there seems to be a momentum towards a common external fiscal strategy with significant consequences - namely, sanctions against noncompliant third countries - despite the EU having no real competence to impose such sanctions. In fact, the institutions and other unofficial actors involved in many of these developments are accused of arbitrariness, bias in favour of Member States and lack of transparency in their workings and deliberations. All of the above potentially undermine the attractiveness of the $\mathrm{EU}$ as a good corporate tax destination.

At the time of writing, from a purely legalistic perspective, Brexit does not appear to have an immediate impact on the above analysis. In fact, the status quo is likely to be perpetuated vis-à-vis the UK. Under the draft Withdrawal Agreement between the UK and the $\mathrm{EU},{ }^{262}$ whose ratification by the UK

\footnotetext{
${ }^{261}$ This area was not examined in this paper. For more information, see HJI Panayi, 'European Community Tax Law' (n 28) ch 19 [11]-[12].

${ }^{262}$ See European Commission, Draft Agreement on the Withdrawal of the United Kingdom of Great Britain and Northern Ireland from the European Union and the European Atomic Energy Community, as Agreed at Negotiators' Level on 14 November 2018 (Web Page, 14 November 2018) ('Withdrawal Agreement') <https://ec.europa.eu/commission/publications/draftagreement-withdrawal-united-kingdom-great-britain-and-northern-ireland-european-unionand-european-atomic-energy-community-agreed-negotiators-level-14-november-2018_en>. For an overview of the issues, see European Commission, Brexit Negotiations: What is in the
} 
Parliament in its current form is most unlikely, ${ }^{263}$ the UK will be treated during a transition period ${ }^{264}$ as if it is still part of the EU, but without any involvement in the EU institutions and governance. Therefore, the UK will continue to be bound by EU law, including whatever has been described in this article as being encompassed within the scope of EU corporate tax law. The CJEU will also continue to have jurisdiction during this period. ${ }^{265}$

Even after the transition period has ended, under the Withdrawal Agreement, the UK will be bound to continue to apply the provisions of the $D A C^{266}$ and of the $A T A D^{267}$ as applicable at the end of the transition period. In other words, any further amendments to these Directives made in the transition period, during which the UK will have no vote and no right to object, will also be binding on it. Similarly, the UK will also be bound by the Code of Conduct on Business Taxation and all guidance as applicable at that point in time. ${ }^{268}$ Crucially, the draft Withdrawal Agreement commits the UK to good governance in the tax area, which includes, 'the global standards on transparency and exchange of information, fair taxation, and the OECD standards against Base Erosion and Profit Shifting (BEPS)'. ${ }^{269}$ The preceding Political Declaration contains similar provisions. ${ }^{270}$ The EU and the UK are

Withdrawal Agreement (Fact Sheet, 14 November 2018) <http://europa.eu/rapid/pressrelease_MEMO-18-6422_en.htm>. See also European Commission, Outline of the Political Declaration Setting Out the Framework for the Future Relationship between the European Union and the United Kingdom of Great Britain and Northern Ireland, as Agreed at Negotiators' Level on 14 November 2018 (Web Page, 14 November 2018) $<$ https://ec.europa.eu/commission/files/outline-political-declaration-setting-framework-futurerelationship-between-european-union-and-united-kingdom-great-britain-and-northern-irelandagreed-negotiators-level-14-november-2018_en>.

${ }^{263}$ At the time of writing, the UK Parliament has rejected the draft Withdrawal Agreement three times.

${ }^{264}$ Initially, the transition period was expected to come into effect after the UK officially exited the EU on 29 March 2019 and to last until the end of 2020. As the Withdrawal Agreement was not ratified by the UK Parliament, Brexit was delayed and two further extensions were granted by the EU to the UK to come up with alternative arrangements, the latest one expiring on 31 October 2019.

${ }^{265}$ Under certain circumstances, the CJEU is expected to continue to have jurisdiction after the transition period though the provisions of the Withdrawal Agreement are not very clear on this point.

${ }^{266}$ Withdrawal Agreement (n 262), Annex 4, art 2(a).

${ }^{267}$ Ibid art 2(b).

${ }^{268}$ Ibid art 3.

${ }^{269}$ Ibid art 1.

${ }^{270}$ See General Secretariat of the Council, Political Declaration Setting Out the Framework for the Future Relationship between the European Union and the United Kingdom (Report, doc 
expected to promote good governance in tax matters, improve international cooperation in the tax area and facilitate the collection of tax revenues. This is likely to substantially curb the power of the UK to engage in aggressive tax competition, should it choose to do so in the post-Brexit era. In fact, the UK might not even be able to engage in any form of tax competition that focuses on attracting investment through the selective conferral of tax incentives to certain industries or undertakings. This is because the Withdrawal Agreement includes commitments by the UK to be subject to the joint surveillance powers of DG COMP and the UK Competition Authority to ensure consistency on state aid matters. ${ }^{271}$

These commitments have been criticised as locking in the UK for an indefinite term and limiting its post-Brexit policy options, including its corporate tax policy options. ${ }^{272}$ It is not surprising that, at the time of writing, the UK Parliament has overwhelmingly rejected the Withdrawal Agreement three times and an extension period for departing from the EU was eventually given by the EU at the UK's request. This extension period will end on 31 October 2019. No one quite knows what is going to happen after the period has elapsed and whether there will be a soft Brexit (that is, with a deal) or a hard Brexit (that is, without a deal). Following the resignation of the UK Prime Minister Theresa May after the European Parliament Elections in May 2019, the governing Conservative Party elected Boris Johnson as the new Prime Minister on 23 July 2019. Johnson was the leading advocate of the Leave campaign and has advocated a no-deal Brexit in case the EU does not renegotiate its Withdrawal Agreement. However, the EU has reiterated that there will be no further renegotiation of the Withdrawal Agreement. ${ }^{273}$ Whilst the UK seems to be marching towards a hard Brexit, it would seem that very minimal preparations

XT 21095/18, Council of the European Union, 22 November 2012) Part II, XIV [79] <https://www.consilium.europa.eu/media/37059/20181121-cover-political-declaration.pdf>.

${ }^{271}$ It had already been announced at an earlier stage of the negotiation process that the UK would maintain a rigorous state aid control system, even in the no-deal scenario, and that the UK Competition authority would take on the role of enforcement and supervision for the whole of the UK. See the guidance published by the UK Government on 23 August 2018 to inform citizens and business how state aid rules would apply in the event of a no-deal Brexit: 'Guidance: State Aid if There's No Brexit Deal' Gov.UK (Web Page, 23 August 2018) <https://www.gov.uk/government/publications/state-aid-if-theres-no-brexit-deal>.

272 This is one of the main reasons why the draft Withdrawal Agreement was rejected three times by the UK Parliament. The Irish backstop was also a major source of concern. For a general overview, see Tom Edgington, 'Brexit: What Deal Did MPs Reject?', BBC News (online, 29 March 2019) <https://www.bbc.com/news/uk-politics-47745831>.

${ }^{273}$ See one of the many reports available at: Jon Stone, 'EU Leaders 'Unanimous There Will Be No Renegotiation of Brexit Deal, Says Juncker', Independent (online, 21 June 2019) <https://www.independent.co.uk/news/uk/politics/brexit-news-latest-theresa-may-no-deal-euexit-a8968756.html>. 
have been made for it, at least in the tax field. ${ }^{274}$ From a corporate tax perspective, if the UK leaves without a deal, then it will be treated as a third country and UK investors stand to lose the protection of the fundamental freedoms and EU secondary legislation, although they will still benefit from the free movement of capital.

In any case, the EU should not bask in the illusion of success as far as the Brexit negotiations on taxation are concerned (with or without a deal), for the EU system of corporate tax law is deeply flawed and in urgent need of some cohesion and coordination. As already explained, the current system is a patchwork of sometimes contradictory rules and ad hoc solutions, often combined with lack of institutional accountability or transparency.

Ironically, Brexit might prove to be a catalyst for more extensive harmonisation in the EU legal order, at least as far as corporate tax policy is concerned. To a large extent, it is the lack of further harmonisation which has led to the often uncoordinated results and historical compromises that we have today. On a political level, the UK has long been considered as one of the more recalcitrant Member States, ${ }^{275}$ though, admittedly, not the only one averse to further tax harmonisation. The UK's stance against the European Commission's proposals for the FTT and, less emphatically, the CCCTB is indicative of this recalcitrance. Whatever the final withdrawal deal, if any, the vacuum to be left by the departure of the UK from the EU is unlikely to be filled in the immediate future by any other Member State with the same predisposition against further tax integration and the economic power to back it up. In any case, even before Brexit, the dynamics in the international tax system had already — some would

\footnotetext{
${ }^{274}$ See, eg, 'Guidance: Check Temporary Rates of Customs Duty (Tariffs) on Imports after EU Exit' GOV.UK (Web Page, 13 March 2019) <https://www.gov.uk/guidance/check-temporaryrates-of-customs-duty-on-imports-after-eu-exit $>$. As far as the EU's position is concerned, see the recent Commission Communication of 12 June 2019: 'State of Play of Preparations of Contingency Measures for the Withdrawal of the United Kingdom from the European Union - Includes Annex 1 and Annex 2' $\operatorname{COM}(2019) 276$ final <https://ec.europa.eu/ info/publications/communication-12-june-2019-state-play-preparations-contingencymeasures-withdrawal-united-kingdom-european-union_en>.

${ }^{275}$ See Klaas Staal's LSE blog which shows how Britain has most often taken positions against the majority in the Council of the European Union: Klaas Staal, Britain Has Most Often Taken Positions against the Majority in the Council of the European Union (Blog, 10 November 2017) <http://blogs.lse.ac.uk/brexit/2017/11/10/britain-has-most-often-taken-positions-against-themajority-in-the-council-of-the-european-union/>. This is based on a paper authored jointly with Marco Fantini, where a Member State's influence on decision-making in the Council was assessed on the basis of the voting behaviour of other countries. UK had less support than all other Member States. See Marco Fantini and Klaas Staal, 'Influence in the EU: Measuring Mutual Support' (2018) 56(2) Journal of Common Market Studies 212, $216<$ https:// onlinelibrary.wiley.com/doi/epdf/10.1111/jcms.12586>.
} 
say irrevocably - changed and the polemic against base erosion and profit shifting simply facilitated further tax integration in the EU. In other words, the process for further corporate tax harmonisation may have already started, with or without the UK's input and involvement. It is hoped that this process will help resolve the problematic issues discussed in this article and address the peripatetic nature of EU corporate tax law. Whether the UK is about to embark on its own peripatetic adventure as far as its corporate tax system is concerned, that remains to be seen. 